\title{
Ética y política en sinfonía levinasiana y derridiana
}

\author{
Ethics and Politics in Levine and Derridian \\ Symphony
}

Ética e politica na sinfonia levinasiana $e$ derridiana

Éthique et politique en symphonie lévinasienne et derridienne

列维纳斯和德里达交响曲中的伦理与政治。

\author{
David E. Kronzonas ${ }^{1}$ \\ Universidad de Buenos Aires - Argentina
}

Revista Derechos en Acción ISSN 2525-1678/ e-ISSN 2525-1686

Año 5/Nº 14, Verano 2019-2020 (21 diciembre a 20 marzo), 327-399

DOl: https://doi.org/10.24215/25251678e363

ORCID: https://orcid.org/0000-0002-1303-6227

Recibido: $15 / 02 / 2020$

Aprobado: 01/03/2020

Resumen: El diálogo filosófico entre Derrida y Levinas consta de cuatro textos: tres, firmados por Derrida (Violencia y metafísica, 1964; En este momento mismo en esta obra heme aquí, 1980; y Adiós a Emmanuel Levinas, 1997 y; sólo uno por Levinas (Completamente de otro modo, 1973). Entre ambos autores hay una referencia silenciosa, constante, sostenida, empática respecto del discurso de cada cual. Derrida utiliza una metáfora interesante para explicar esta relación cercana: afirma que la herencia nos precede y nos elige, nos invoca antes de que podamos

\footnotetext{
1 Abogada (UNLP), Magister en Derecho Administrativo (Universidad Austral); Master en Administración, Derecho y Economía de los Servicios Públicos de las Universidades Carlos III -Madrid-, París X -Nanterre- Francia y El Salvador -Buenos Aires, Argentina; docente de Derecho Administrativo en la Universidad de Buenos Aires y Universidad Austral.
} 
elegirla, y que de alguna manera, estamos obligados a responder a ese legado. Levinas nos hablará -en cambio- de filiación. Podríamos decir que Derrida y Levinas se heredan entre sí. Existe en ambos una llamada a reafirmar, atender o mantener el legado que cada uno recibe del otro y que convive con la necesidad de interpretar, escoger y transformar esa herencia. Las tradiciones griegas y judías confluyen en los dos.

Palabras claves: Ética - Política -Estado justo

Abstract: The philosophical dialogue between Derrida and Levinas consists of four texts: three, signed by Derrida (Violence and metaphysics, 1964; At this very moment in this work here I am, 1980; and Farewell to Emmanuel Levinas, 1997 and; only one by Levinas (Completely different, 1973). Between both authors there is a silent, constant, sustained, empathic reference to each other's discourse. Derrida uses an interesting metaphor to explain this close relationship: he affirms that heritage precedes and chooses us, he invokes us before we can choose it, and that somehow, we are obliged to respond to that legacy. Levinas will instead speak to us of filiation. We could say that Derrida and Levinas inherit from each other. There is a call in both of them to reaffirm, attend to or maintain the legacy that each one receives from the other and that coexists with the need to interpret, choose and transform that heritage. Greek and Jewish traditions converge in both.

Keywords: Ethics - Politics - Fairness

Resumo: 0 diálogo filosófico entre Derrida e Levinas consta de quatro textos: três, assinados por Derrida (Violência e metafísica, 1964; Neste momento mesmo deste trabalho, estou aqui, 1980; e Adeus a Emmanuel Levinas, 1997 e; apenas um por Levinas (Completamente de outra forma, 1973). Entre os dois autores há uma referência silenciosa, constante, sustentada, empática respeito do discurso de cada um. Derrida usa uma metáfora interessante para explicar essa estreita relação: ele afirma que a herança nos precede e nos escolhe, invoca antes que possamos escolher, e que de alguma forma estamos compelidos a responder a esse legado. Levinas falará -em vez disso- de filiação. Poderíamos dizer que Derrida e Levinas se herdam mutuamente. Existe em ambos um chamado a reafirmar, atender ou manter o legado que cada um recebe do outro e que coexiste com a necessidade de interpretar, escolher e transformar essa herança. As tradições grega e judaica se reúnem em ambos. 
Palavras-chave: Ética - Política - Estado justo

Resumè: Le dialogue philosophique entre Derrida et Levinas se compose de quatre textes: trois signés par Derrida (Violence et métaphysique, 1964; à ce moment même de cette œuvre je suis ici, 1980; et Adiós a Emmanuel Levinas, 1997) et; un seul de Levinas (complètement différent, 1973). Entre les deux, il y a une référence silencieuse, constante, soutenue et empathique au discours de l'autre. Derrida utilise une métaphore intéressante pour expliquer cette relation étroite: il dit que I'héritage nous précède et nous choisit, nous invoque avant que nous puissions la choisir, et que nous sommes, d'une certaine manière, obligés a lui répondre. En revancha, Levinas nous parle de filiation. On pourrait dire que Derrida et Levinas héritent I'un de l'autre. II y a, dans les deux, un appel à réaffirmer, assister ou maintenir l'héritage que chacun reçoit de l'autre et qui coexiste avec le besoin d'interpréter, de choisir et de transformer ce patrimoine. Les traditions grecque et juive se rejoignent dans les deux.

Mots-clés: Ethique - Politique - Etat juste

摘要: 德里达和列维纳斯之间的哲学对话包括四个文本:三个, 由德 里达签署。两位作者之间都对彼此的话语保持沉默，持续，持续，善 解人意。在我们选择它之前先调用我们, 然后我们必须以某种方式 对这一遗产做出回应。重申, 关注或维护彼此继承的遗产, 并与解释, 选择和改造该遗产并存的需求并存。希腊和犹太传统在这两者中融 合在一起。

关键词: 伦理, 政治, 公正国家

I. Entre ética y política existe una relación de mutua dependencia. No podría haber justicia sin ética, ni ética sin justicia. La amenaza de la tiranía ${ }^{2}$ y los modelos políticos fundados en

2 En La Democracia en América, Tocqueville -en un esquema influido claramente por Rousseau- dice que la igualdad es ahora casi un hecho providencial; que nadie cree ya en la justicia de los principios en que se fundaban las antiguas distinciones de rangos 0 clases (...) "La única cuestión que quedaba era la de saber si la libertad puede acompañar a la igualdad o si de ésta resultará, la tiranía universal". Allan Bloom. Gigantes y enanos. 
una totalidad cerrada (el fascismo, el nazismo, el estalinismo; así como los recientes sucesos latinoamericanos tanto en Ecuador, en Chile y en Colombia de revueltas populares frente a la crisis hegemónica neoliberal que se han traducido en represión sangrienta por parte de sus elites -dónde se naturaliza la diferencia entre ricos y pobres-; y en el golpe de Estado en Bolivia -donde nuevamente, una y otra vez, se prioriza el clasismo y el racismoson algunos ejemplos dónde se cristaliza la comisión del mal por el $\mathrm{mal}^{3}$, de la aniquilación por la aniquilación ${ }^{4}$ revelando el sentido mismo del sufrimiento y haciendo empírico el olvido de la imposibilidad ética de justificar el sufrimiento del Otro) muestran que entre la ética y la política debe establecerse un vínculo que obligue a ambas dimensiones a permanecer en tensión; pero también, se propone desterrar todo esquema de deducción de la política a partir de la ética. La relación entre ética y política sólo sería fecunda en la medida en que la ética inspire a la política. ¿Cómo lograrlo? La dimensión ética debería atravesar lo

Interpretación sobre la historia socio-política de Occidente. Gedisa Editorial, Buenos Aires, Argentina, 1991, (p. 174).

3 El imperativo categórico de no traicionar la humanidad. La alta traición de la humanidad es el perjurio supremo, el crimen de los crímenes, la falta contra el juramento originario. Traicionar a la humanidad sería pura y simplemente traicionar, faltar a la virtud, faltar a la fraternidad. En esa humanidad no se debería traicionar jamás al hermano. Es otra manera de decir: nunca se traiciona más que al hermano. El fratricidio es la forma general de la tentación, la posibilidad del mal radicial, el mal del mal (Kant).

4 En los orígenes del totalitarismo $\mathrm{H}$. Arendt describe tres momentos para la dominación total de una persona o un pueblo: la muerte de la persona jurídica en el hombre, el asesinato de la persona moral y la muerte de la individualidad. El sistema nazi había elevado la aniquilación a un fin en sí Mismo. Veía en su análisis de los campos de concentración un ataque contra el espíritu humano. Ese libro fue un intento de universalizar la experiencia judía, una explicación del significado moral y legal de un crimen contra la humanidad y un intento de señalar un camino hacia adelante, de manera de sugerir formas que pudieran restaurar la humanidad. Arendt quería que los judíos fueran la vanguardia de un nuevo cosmopolitismo. Universalismo que implicaba la renuncia a las propias raíces étnicas y culturales. Arendt decía que sólo amaba a sus amigos y el único amor que conocía y creía era el amor de las personas. Hay aquí cierta resonancia de aquello que en 1916 escribía Rosa Luxemburgo a su amiga Matilde Wurm: "( ...) me siento en casa en todo el mundo, donde sea que haya nubes, aves, lágrimas humanas." El judaísmo era un rasgo esencial de su identidad pero ello no acarreaba obligación, solidaridad o visión alguna. 
político a fin de evitar que la política se cierre sobre sí misma. La ética funciona como una suerte de resistencia a los sistemas políticos fundados en totalidades cerradas. La figura del tercero abre la necesidad de la justicia y del Estado. La relación entre ética y política se centrará en establecer el vínculo entre el orden estatal y la dimensión del "cara a cara". La estructuración de un Estado justo (Abensour -apelando a la filosofía política antigua) ${ }^{5}$ -y contrapuesto al Leviatan ${ }^{6}$ de T. Hobbes- se fundamenta en la proximidad de la ética. Hay dos momentos en el pensamiento levinasiano: el de Totalidad e Infinito en que se manifiesta crítico de la política. Allí lo político significa una suspensión de la ética y donde ésta se constituye a partir de su oposición; y por otro lado, el De otro modo que ser (...) en el que existe la posibilidad

5 Abensour, Miguel, “El mal elemental” en Levinas, Emmanuel Algunas reflexiones sobre la filosofía del hitlerismo Fondo de Cultura Económica, Buenos Aires, Argentina, 2001. Nietzsche decía que un hombre que decide vivir su tiempo, debe salirse de él. Salirse de su tiempo significa conocer a los griegos.

6 El contractualismo moderno se corresponde con lo que Hegel llama la perspectiva del entendimiento. Según Hegel las teorías sobre el contrato social parten de la suposición de seres autónomos y egoístas que por conveniencia realizan el acuerdo que constituye y da fundamento al Estado. Se privilegia el egoísmo de los particulares, en la medida en que la instancia universal (el Estado) es entendido como mero útil. El Estado deviene el instrumento para garantizar que cada individuo pueda perseguir sus fines egoístas. De acuerdo con esa perspectiva el Estado es el resultado del acuerdo entre estos individuos (egoístas). El cuerpo común estará fundado en el arbitrio de los individuos que pretenden a través de aquel, garantizar sus propios intereses. En esta crítica al contractualismo aquello que está en juego es la mediación entre lo particular y lo universal. Si bien éste privilegia lo particular en virtud del egoísmo y entiende lo universal, como apéndice, como instrumento funcional que busca garantizar los intereses egoístas; Hegel invierte los términos: lo universal -que históricamente aparece después- es el fundamento de lo particular, que no es otra cosa que lo universal particularizado. El momento de eticidad se hará efectivo en la idea del Estado que se auto-presenta como unidad en la inmediatez a través de la sociedad civil. En el momento dialéctico de reconciliación, lo particular no se anula, sino que es parte de la verdad que no puede suprimirse. Los sujetos individuales tiene su verdad en virtud de lo universal (el Estado). Éste es condición de posibilidad de realización de la verdad del individuo. Si se considera al Estado en términos contractuales el fin último coincidirá con los motivos subjetivos para pactar la unión común. Ser y verdad se presentan bajo la modalidad de la totalidad. Un Estado autosuficiente y autónomo, donde los individuos cobran significado en virtud de un orden que los engloba; un Estado total que absorbe toda exterioridad. Lógica política que imposibilita la ética. El mero acontecer de lo político que experimenta la deshumanización de lo humano en los acontecimientos del siglo XX. 
de trazar un vínculo positivo con la ética, a través de la figura del tercero. Levinas es un pensador de la excedencia. ${ }^{7}$ A partir del segundo momento se torna necesario el establecimiento de una dimensión de visibilidad del rostro. La figura del tercero reintroduce la conciencia, la tematización y el saber, suspendidos en el momento propiamente ético. El tercero conlleva la problemática de la multiplicidad y torna necesaria la re-significación del rostro situado entre la excedencia y la visibilidad.

La política requiere de la ética para no quedar librada a sí misma, evitando con ello el riesgo de la tiranía. Por otro lado, la ética no puede dar cuenta de la justicia institucional, clamada por el tercero y en este sentido, la política se torna necesaria. No debe haber entre ambas esferas, derivación o fusión. El movimiento de re-totalización que instaura lo institucional debe consistir en una suerte de totalidad porosa, por la que el Estado justo -que surge de la limitación de la proximidad- no anule la relación "cara a cara". Levinas llama y convoca a la apertura, a la ética, a la alteridad del Otro en una exterioridad de la existencia también primordial. El olvido filosófico y fáctico del Otro ha definido la realidad histórica como el mero acontecer de lo político. Sin embargo, Levinas no se refiere a la política en términos generales sino a aquella que queda librada a sí misma, a aquella que responde a la ontología de la totalidad; que al no dar lugar a una exterioridad, imposibilite la ética. En suma, si bien la política engendra el riesgo de la tiranía, también abre a la necesidad de un orden político justo donde la vida sea más importante que la muerte, la supervivencia no sea accidental u ocasional, ni la destrucción la regla del cotidiano.

7 Levinas no realiza descripción ninguna del "mejor régimen" Es el origen ético de toda significación lo que permitirá que ésta cuestión sea investida a partir de su excentración, arruinando así la posibilidad de su tratamiento autónomo del campo de la filosofía política. La excedencia ética no se proyecta hacia la neutralidad del bien sino hacia el otro. La excedencia se ventila en la metáfora de los dos soles platónicos que viene a iluminar el sol visible. Bachellard se preguntaba sino ¿era el la fuente necesariamente nocturna de toda luz? Además debemos tener en cuenta que el sol de Platón no ilumina sino que engendra. El Bien es el padre del sol visible que da a los seres "la generación, el crecimiento y la alimentación". (Platón. La República, 508a; 509b.). 
Levinas reconoce el valor institucional en oposición a la tiranía. Para ello, parte de una concepción de la libertad que devela la posibilidad de traicionarse. El hombre lleva en su corporalidad la posibilidad de traicionar su propia voluntad. La libertad es quebrantable; podrá permanecer indiferente, podrá mantenerse libre, pero la corporalidad la pone en riesgo. La libertad puede quebrarse en la tortura o traicionarse incluso en el pensamiento. ${ }^{8}$ La libertad conjuga el problema político mismo. El hecho de que la libertad puede ser modificada o incluso anulada por la violencia de los hombres clama por instituciones (justas). La posibilidad de un Estado que aspire a la justicia abre la oposición a la tiranía. Sólo a través de él, la esencia violable de la libertad puede ser aplazada o quizás incluso también, suspendida. El orden institucional surge en pos de garantizar las libertades. La teoría política enseña que la libertad sin la garantía de la ley se torna ingenua. La necesidad de la institucionalidad como garantía de la libertad abre una interesante perspectiva. Habrá que tener en cuenta que la buena voluntad por sí misma no es libertad verdadera, en tanto no dispone de los medios para realizarse. Así -en una suerte de paradoja- el máximo defensor de la alteridad del Otro y detractor de la totalidad parece recurrir a una solución de corte hegeliana; aquella en que la libertad subjetiva debe objetivarse por el Estado. A pesar de ello, no retorna a un sistema político que se fundamenta en una totalidad cerrada. A pesar de ser un anti-hegeliano convencido, Levinas propone que ese sistema reconozca la necesidad de la institucionalización abriendo la puerta a una interioridad capaz de abrirse al Otro. La ética es la vía de resistencia a la totalidad en general y en particular, a los regímenes políticos en los que la alteridad se disuelve. El sujeto se constituye como ser libre; ya no como portador de una subjetividad heroica. La vía interior de resistencia será la de un sujeto responsable -incluso antes de la libertad- ante el rostro

8 En la novela "1984" de G. Orwell; el verdugo 0`Brien le propicia tormentos hasta que el protagonista, Winston admite que dos más dos es igual a cinco. Para acallar las voces hace falta que la libertad se traicione, que admita como verdaderas las más evidentes mentiras.- 
del Otro, tal como se revela al yo en su alteridad absoluta. Si aún se corre el riesgo de que lo político engendre una totalidad cerrada y absorba la alteridad del Otro, la ética deberá funcionar como una suerte de alarma de la política.

Rápidamente se interpreta a Emmanuel Levinas como un pensador de la ética -el filósofo de la ética del siglo XX-dicen muchos. Efectivamente, la ética recorre sus escritos pero no se comprenderá en su complejidad sino se tiene en cuenta que son las ontologías de la totalidad, la política como guerra y como tiranía y el Estado total lo que en definitiva anula la alteridad del Otro. La ética es aquello que la misma tradición filosófica ha olvidado en el diseño de modelos totalizantes de la existencia humana; pero a su vez, es aquello que se opone a la totalidad sin excedencia. En el prólogo de Totalidad e Infinito, Levinas opone la política a la moral; siendo la política definida como el arte de ganar la guerra. La ética -entendida en ese texto como paz mesiánica- abre sin dudas, una instancia más allá de la política de la totalidad. La ética se opone a un sistema político como el hegeliano donde las singularidades son parte de una totalidad ontológica que se auto-produce. Hegel postulaba una concepción del individuo basada en la defensa de la subjetividad egoísta. Un individuo sólo realiza su verdad en tanto y en cuanto es parte de lo universal, es decir y en este caso, del orden estatal. La ética levinasiana postula una nueva perspectiva que se aleja tanto del esquema que lo convierte en un momento dialéctico del Estado, como de la exaltación de la individualidad egoísta. Totalidad e Infinito se presenta como una defensa de la subjetividad, como resistencia a ser absorbida en la totalidad pero no a partir del sujeto egoísta sino de la responsabilidad ante el rostro del Otro. La vía de ruptura en sus dos obras principales -la arriba señalada y en De otro modo que ser (...)- se centrará en la constitución de un sujeto ético responsable ante el rostro del Otro y no reducible a la totalidad.

Levinas da cuenta de una concepción original de la subjetividad -una filosofía de lo propiamente humano- que se aleje 
tanto de la idea de un sujeto que en su afán de conocimiento reduzca la alteridad a la Mismidad; como del modelo hegeliano que define la realización del individuo en la medida en que es parte del todo (del Estado ético). Ello permitirá la concreción de la relación ética entre yo y el Otro; donde el primero se define fundamentalmente como ser-para-otro y el segundo, como rostro. Levinas propone en Totalidad e Infinito comenzar por la noción de gozo, definida como la felicidad egoísta del yo, categoría comprendida como condición necesaria de la constitución del sujeto ético entendido como "para-otro". Sin embargo, esta categoría resultará en definitiva incapaz de romper con la lógica de la totalidad. El gozo como figura de la subjetivación es una relación con el mundo mediante la sensibilidad. Levinas tiene una doble pretensión: la de mostrar que la figura del gozo se aleja de ser una relación cognitiva (de representación) con el mundo; así como, de darle a las cosas una dimensión de mera utilidad (Heidegger). Esa sensibilidad propuesta resultará meramente ingenua ya que mediante ella no se constituye el mundo; el sujeto sólo goza de él. El gozo es un vínculo con las cosas, prescindiendo de su finalidad. La relación de gozo con el mundo no supone un sujeto previo a esta relación, sino que -en el mismo vínculo gozoso con el mundo- el sujeto se constituye en su felicidad egoísta. Definido positivamente a través de la fórmula "vivir de" dónde el gozo es comprendido a partir de las necesidades, el "vivir de" como gozo significa la felicidad, como vínculo irreflexivo con el mundo del cual, se goza. El trabajo es alimento del gozo, sin otra felicidad más que él mismo. Levinas se alejará de la idea que las necesidades son carencia o imperfección para someterlas a una lógica de dependencia/ independencia. En virtud de las necesidades el ser humano queda abierto a la dimensión del gozo. A partir de las necesidades el hombre se independiza de la vida como mera conservación. La figura del trabajo hace que las cosas sean poseídas, aprehendidas, puestas a disposición como lo que permanece en el tiempo.

Sin embargo, la mera satisfacción de necesidades egoístas imposibilita que ella sea una apertura a la alteridad, impide que 
sea una figura que dé lugar a la exterioridad no asimilable. El gozo resultará insuficiente para apartarse de la filosofía de lo Mismo. Habrá que recordar que la constitución de la subjetividad ética en Totalidad e Infinito está dispuesta como deseo. El gozo es lo que se contrapone al Deseo del Infinito y lo que lo hace posible. El deseo -a diferencia de la necesidad- se caracteriza por no buscar la satisfacción. Deseo insaciable que no reclama alimento. Movimiento del Mismo al Otro, sin retorno al primero. Por otra parte, el movimiento de gozo -como satisfacción de necesidades- permitirá al yo abrirse a aquello que no le falta. El Deseo metafísico permite el tránsito de la Mismidad a la alteridad. Es metafísica de la separación infinita. Es apertura y libertad. ${ }^{9}$ En De otro modo que ser (...) radicaliza la apertura a la ética como la filosofía que da lugar a la alteridad irreductible del Otro a través de dos nociones fundamentales: el desinterés y la vulnerabilidad. Levinas opone: guerra -egoísmos que luchan unos con otros, todos contra todos y al mismo tiempo en conjunto- a la que define como el gesto o drama de la esencia; a la paz mesiánica -vinculada al desinterés y dónde la subjetividad más allá del ser es constituida a través de una responsabilidad que se cristaliza en la preocupación por la muerte y el sufrimiento del Otro.

Introduce el concepto de vulnerabilidad como el modo de la sensibilidad -independiente del saber y de la tematización- por la cual, el sujeto se instituye como rehén, atravesado por la obsesión del Otro. Sólo a través de la corporalidad ofrecida al Otro -como piel desnuda y vulnerable- tiene la ética, un sentido más allá del ser. Materialidad ofrecida al Otro, subjetividad única e irreductible al género, de responsabilidad intransferible. La identificación de la subjetividad con

\footnotetext{
9 Tanto la fenomenología como la ontología serían para Levinas filosofías de la violencia. A través de ellas, toda la tradición filosófica estaría ligada a la opresión y el totalitarismo de lo mismo. Vieja amistad entre la luz y el poder; vieja complicidad entre la objetividad teórica y la posesión técnico-política. Si se pudiese poseer, captar y conocer lo otro, no sería lo otro. Poseer, conocer, captar son sinónimos del poder. Ver y saber, tener y poder sólo se despliegan en la identidad opresiva y siempre luminosa de lo Mismo.
} 
la vulnerabilidad completa su proyecto inicial. En Totalidad e Infinito el deseo aún representa un movimiento de la subjetividad, un dirigirse de un yo colmado. En De otro modo que ser (...) la pasividad más pasiva que cualquier otra pasividad cobra esta dimensión en la figura de la vulnerabilidad. Lo humano -señala Levinas- se ofrece a una relación que no es poder. La vulnerabilidad es el lugar propio de la posibilidad de la ética en la medida en que es apertura pasiva al Otro. Se pueden distinguir en Levinas tres acepciones de la pasividad: La primera, donde la responsabilidad ante el Otro se visualiza, no como el correlato de una voluntad libre sino como la imposición de responder ante la epifanía del rostro; el segundo, el movimiento de ruptura de la representación a través del rostro del Otro y el tercero, el vinculado con el primer mandato ético: "No matarás". Constituir al sujeto bajo la pasividad más pasiva que cualquier otra pasividad- significa aplazar la libertad, perder los poderes de representación y revelar el carácter inviolable del rostro por su misma resistencia. Insiste una y otra vez en alejar la responsabilidad ética de un acto de conciencia de un sujeto libre. Por el contrario, la responsabilidad resultará constitutiva de la subjetividad porque el sujeto es elegido e irremplazable. Es por ello, que la dimensión humana tiene un sentido ético.

Nada más lejos de la ética levinasiana una interpretación que asocie el encuentro ético con una suerte de bondad inherente al ser humano. La responsabilidad ética -ante el rostro del Otro- no es una cita ingenua y deliberada con el Bien. La responsabilidad para con los Otros jamás podrá significar voluntad altruista, benevolencia natural o amor. Anterior -absoluto, anárquico y sin tiempo- a la propia voluntad, la subjetividad como responsable es elegida incluso y casi siempre a su pesar. Ni la benevolencia, ni la lucha resultan figuras aptas para describir el encuentro ético. Se trata de un encuentro por el cual, más allá de la libertad, el sujeto es rehén de una responsabilidad intransferible. Pasividad que desvincula la responsabilidad de la libertad y que también significa, pérdida del poder 
representacional ${ }^{10}$ del sujeto -en la medida en que el rostro es para Levinas irrepresentable, una excedencia inabarcable-. El rostro es por excelencia lo no reductible, su misma expresión inaugura un sentido independiente del lenguaje predicativo. La alteridad del Otro es absoluta. Su diferencia no puede recaer en sus cualidades susceptibles de ser conocidas. El rostro se expresa requiriéndome, pero en esa imposición formula su alteridad. La alteridad invita a pensar la filosofía desde un foco diferente de la tradición; desde los márgenes y las aporías (Derrida), desde tensiones que no pueden ser resueltas, ni pasadas por el tamiz de la dialéctica, que no pueden ni podrán ser englobadas en un conjunto más vasto, sin que ello constituya una pérdida. Los espectros que desbaratan el tiempo lineal y homogéneo de la existencia, que habitan el duelo infinito de las comunidades, de sus historias (las contadas y las ocultadas), reaparecen interpelando nuestro presente (Benjamin).

En la relación ética, el Otro no expone sus cualidades, es despojado de ellas. El Otro es rostro desnudo, individualidad única que se expresa por fuera de todo concepto. Si el rostro escapa al poder es porque no puede ser representando y porque el mandato ético indica la imposibilidad de asesinato. El sufrimiento excede a la conciencia, es inasumible, no puede ser integrado a un orden, pero a la vez significa un grito y un socorro del Otro a los demás. El sufrimiento del Otro es el absurdo, el sin sentido mismo, lo abismal. El único sentido

10 La representación está dentro de las figuras de la filosofía de lo Mismo, en la media en que ser inteligible es ser representativo y por ello, ser a priori. Reducir una realidad a su contenido pensado es reducirla al Mismo. La lógica de la representación implica la pérdida de la individualidad de lo representado que se ve reducida al representante, es decir al contenido pensado por el Mismo. La correlación del movimiento del Yo al Otro que retorna al Yo a través de la representación es la de un lenguaje fundamentalmente predicativo por el cual, el Otro es descriptivo. Si en el encuentro con el Otro se redujera a una relación cognoscitiva la diferencia inaugurada por la presencia de su alteridad podría ser dicha en relación con el yo que conoce y tematiza. El Otro pierde su unicidad, se transforma en el referente de un concepto, por el cual pierde su alteridad irreductible. El rostro identificado con su diferencia es un rostro despojado de su alteridad. Ese rostro ya no acusa, ya no suplica. La representación significa hablar de dominio y poder sobre el Otro. 
que puede tener ese sufrimiento es el de mi sufrimiento por el Otro: el socorro ante el sufrimiento del Otro y la experiencia del mandato ético de no dejar al Otro sólo ante su propia muerte se corresponde con la constitución de una subjetividad abierta a la responsabilidad ética, a la imposibilidad de dejarlo en soledad ante su dolor, ante su carencia. Imposible abandono del Otro a su desamparo y cuyo sentido comienza e inaugura lo interhumano.

Levinas llama a repensar la institucionalidad política en tanto garantía de las libertades esencialmente vulnerables. Si la política librada a sí misma incuba una tiranía, la vulnerabilidad de la voluntad -en su posibilidad de traición- clama por un Estado en el que esa traición sea neutralizada. Podrá afirmarse una perspectiva positiva de la política en la medida en que ese orden (político) signifique una resistencia al advenimiento del mal. El desafío será vincular la ética y la política como modos de instrumentar esa resistencia. Encontrar el contra modelo político que se aleje de la tiranía al aplazar la vulnerabilidad de la libertad pero que a su vez, esté atravesado por la ética de la responsabilidad, ese será el desafío. Movimiento de re-totalización que engendre una totalidad porosa, permeable, penetrable, asequible para dar lugar a la dimensión ética. ¿No nos preguntamos quién es el Otro? No lo hacemos ya que no hay deliberación, ni conciencia; tan sólo responsabilidad para con él. Levinas llama desinterés al modo ético de lo interhumano. Pero desde el momento en el que puede haber daño entre el Otro y el tercero deviene necesaria la conciencia del saber. Hora de la justicia y de la política que deben funcionar también, como resistencia al mal. La posibilidad del mal perturba la certeza sobre la suficiencia de la relación cara a cara. Esa posibilidad clama por el saber y la tematización que de manera positiva, la ética ha dejado de lado. La ética funciona como lugar de resistencia al olvido del Otro. La ética es el modo por el que el sujeto es vulnerable, ilimitadamente ante el rostro del Otro. La figura del tercero puede significar un límite para la ética en tanto y en cuanto revela el carácter insuficiente de ésta y 
con ello, la necesidad de la política. La pregunta por la justicia es una pregunta de y para la conciencia. Derrida decía -con acierto- que hay en la ética una violencia potencial, implicada en la imposibilidad de discernir el bien del mal, el amor del odio, el dar del tomar. Por ello, la relación ética debe ser interrumpida en virtud del requerimiento de justicia.

La ética como defensa de la relación cara-a-cara e irreductible a la totalidad constituye un modo de resistencia. (a ella) La crítica de la totalidad estaba centrada en aquella defensa de la irreductibilidad del Otro, sólo posible en la medida en que el rostro es lo invisible mismo. En De otro modo que ser (...) el rostro se sitúa en la ambigüedad visibilidad/ invisibilidad en un claro movimiento de re-totalización. El tercero introduce la noción de justicia institucional y para ello, resultará imprescindible cierto retorno a la ontología atravesada siempre por lo irreductible del vínculo ético. Política, ontología y ética estarán así siempre ligadas. Si el rostro es visible e invisible a la vez es porque la multiplicidad representada en la figura del tercero, conlleva la necesidad del orden político. Dos interpretaciones posibles respecto del tercero: en la primera, encarna cierta exterioridad respecto de la relación ética entre el Otro y el Mismo; la segunda, excluido de esa relación sólo se presentaría, interrumpiéndola; como sí el orden político fuera necesario con posterioridad.

La justicia debería establecerse a partir de una doble injusticia original: la de exclusión del tercero y la ignorancia inicial de sus posibles heridas. En la misma relación ética está implícita la problemática política. Una y otra serían simultáneas revelándose la violencia potencial intrínseca a la ética. La figura del tercero no representa tan sólo el Otro del Otro sino los Otros del Otro, el hecho mismo de que en el mundo es desde el inicio un mundo social. La figura del tercero tal y como se la presenta en De otro modo que ser (...) es intrínseca a la misma relación ética. Ética y política -inseparables de hecho- describen la complejidad del encuentro con el Otro. La política no debe quedar nunca librada a sí misma. El esfuerzo levinasiano no 
puede significar la negación del hecho evidente de la existencia de un mundo problemático, social y político. Mostrar el olvido de la alteridad del Otro y su reducción a la mismidad no debe justificar el olvido de la problematicidad política atravesada por la multiplicidad. Que el rostro sea el Otro y el tercero a la vez da cuenta que para no absorber su alteridad, el Infinito se torna invisible pero a su vez, está inmerso en un espacio común con Otros. Dicho esfuerzo está acompasado por Derrida quien señala que si toda amistad es de alguna manera política, la amistad -estrictamente o propiamente política- no es más que una especie de amistad. Se trata de una amistad que no se funda ni en la virtud, ni en el placer sino en la utilidad. La amistad que se llama política está fundada en la asociación o en la comunidad con vistas a lo útil. Dos son los rasgos de lo político: comunidad y derecho. La amistad fundada en lo útil es justicia política (Aristóteles). La amistad política quiere la igualdad. Tiene como proyecto decidido y declarado el de estar fundada en la igualdad. Situación que contrasta con la visión liberal individualista que celebra la sociedad de consumo y la libertad que ofrecen los mercados. La igualdad como ideal democrático se ve afectada. Aquella filosofía política antigua proponía el conflicto entre lo bello y lo útil: la amistad ética es ciertamente más bella; pero la amistad útil es más necesaria ya que exige la concordia, el acuerdo, el consenso. Sin embargo, la responsabilidad viene del otro antes de todo "socius" organizado, antes de toda "politeia", antes de todo "gobierno" determinado, antes de toda "ley". Se responde primero al otro y ante el otro. El otro heterónomo excede, sobrevive, sucede, desborda la autonomía. Se trata de pensar una alteridad en la raíz de la democracia. Quizás ya sea el tiempo de separar el liberalismo de la democracia.

Lo interhumano se ciñe entre el amor ilimitado de la ética y el hecho mismo de la multiplicidad social. Entonces, ¿a quién dar el pan? En Totalidad e Infinito, la justicia se define dentro del campo propio de la ética. La justicia es la respuesta "Heme aquí" ante el llamado del Otro, ante un rostro que limita mi poder y a la vez converge en la más absoluta fragilidad: resistencia del 
rostro, que hace del asesinato del Otro un imposible ético pero que a la vez -irremediablemente-, abre a su posibilidad. Esta noción de justicia -en la que el Otro cuestiona mis poderessupone un vínculo asimétrico por el cual, el dar jamás será recíproco. En la relación ética no le es otorgada al Yo la posibilidad de exhibir su misma alteridad. Ante la trascendencia del Otro, el Yo no podría replicar con su propia trascendencia. El exceso de dar el propio pan no podría esperar la garantía próxima del propio alimento. En De otro modo que ser (...) se prescribe la responsabilidad como unilateral. No puedo esperar que el Otro sea responsable de la alteridad del Yo. En ese texto señalado, la justicia se redefine y sitúa en el campo político, en el terreno de la institucionalidad, del Derecho. Ahora y desde la entrada del tercero, la justicia sólo puede concebirse a partir de la simetría entre las personas. La creación de un espacio común de igualdad, de deberes y derechos sólo puede ser garantizado mediante el principio de igualdad ante la ley. Esto revela la insuficiencia de la ética ya que las heridas infligidas de unos a otros en el ámbito de la multiplicidad conllevarán la necesidad de tematización, de la comparación y de la conciencia. La relación ética asimétrica no basta para establecer la posibilidad de la justicia. La relación con el Otro es de asimetría $^{11}$ y simetría

11 En el cara a cara -en su curvatura bidimensional desigual- yo no soy jamás el Otro y el Otro es jamás yo. Yo y tú no están en posiciones intercambiables, ninguno de los dos puede alternativamente tener el mismo rol u ocupar lugares indiferentemente. Ésta caracteriza la relación ética. La diferencia es siempre del Otro. El Otro llama y yo respondo, pero sin jamás poder evitar oír y esta estructura responsiva de mi subjetividad me expone, en un "Heme aquí" no elegible. Este Ilamado que viene del Otro me llega desde su rostro cuya fragilidad me somete por la altura trascendente desde donde me asigna a la urgencia de su requerimiento. A esta trascendencia yo no puedo replicar con la exhibición de mi propia alteridad, de mi rostro. La ética es ética porque es asimétrica: donde el sujeto está ordenado a la proximidad de un prójimo. Esta unicidad no anula sin embargo la pluralidad. Junto al prójimo hay otro prójimo, el tercero. El Otro no está jamás frente a mí: la relación ética absoluta e inmemorialmente originaria no absorbe en ella, lo que viene después de ella. "La relación ética o asimétrica convoca a una simetrización. Me obliga a comparar las instancias del Otro frente a mí y los requerimientos del tercero de cara al Otro, a entrar así en una tonalidad determinada, destinado a tomar a cargo las modalidades de la comparación y a prevenir posibles violencias. No puede haber inscripción política más que en la simetrización 
a la vez. Ética y Política no se confunden pero la asimetría y la simetría están simultáneamente presentes. Ambas resultan insuficientes por sí mismas y existe dependencia mutua para su realización.

La insuficiencia de la ética consiste en la imposibilidad de la resolución de relaciones interhumanas en un mundo de multiplicidad. Levinas tiene la sospecha que la justicia no debe agotar la resolución de las relaciones interhumanas. La tematización, la comparación, el movimiento totalizador -intrínseco a toda instancia institucional- implican "per se" cierta violencia a lo propiamente humano, en la medida en que la alteridad del Otro queda anulada. Si la figura del tercero muestra el límite de la relación ética y convoca a la justicia; la alteridad del Otro hace de la institucionalidad política un régimen que debe estar bajo interrogación. La violencia es propia del movimiento totalizante que implica la institucionalidad política. Si la figura del Otro no debe negar la aparición del tercero; este no debe negar la irrecusable responsabilidad de la subjetividad hacia el prójimo. Si bien es cierto que la ética resulta insuficiente y hace falta el orden político; no es menos cierto lo inverso. La política para establecerse como un orden justo no puede prescindir de la ética. Levinas se esfuerza por mostrar que la institucionalidad política nunca debe quedar librada a sí misma. La justicia no resuelve por sí la complejidad de lo interhumano. Levinas propone el mantenimiento de una subjetividad absolutamente irreductible a la totalidad.

¿Resulta posible cuestionarse sobre la suficiencia de librar a la justicia frente al problema generado por la entrada del tercero? Levinas señala que la noción de justicia no debe quedar reducida al aparato legal. La problematicidad de la multiplicidad de lo político tampoco puede resolverse en el ámbito meramente

de todas las relaciones, es esto en realidad lo que autoriza la producción de la igualdad, de la reciprocidad de los derechos y de los deberes y la reversibilidad de los lugares y las funciones." Gérard Bensussan. Levinas y la cuestión política en Levinas y lo político. Pablo Dreizick (compilador), Prometeo libros, Buenos Aires, Argentina, 2014, (p. 226).- 
jurídico. De acuerdo con Levinas, la subjetividad se constituye como resistencia a lo jurídico, firmeza en que las lágrimas del Otro no queden absorbidas en la totalidad, como si la defensa de la alteridad del Otro se encarnara en un sujeto ético que es para-el-otro. No sólo el sujeto ético -abierto al rostro del Otrose opone a una institucionalidad devenida injusta sino también, a una concepción que permita que una subjetividad política se oponga a tal institucionalidad en el seno mismo de lo político. No hay en Levinas análisis acabados de la subjetividad política, no hay tampoco un sistema político claro en él; hay sí la denuncia de los peligros que la totalidad acarrea y encierra. Frente a la experiencia histórica vivida considerará a la ética como la dimensión privilegiada de su análisis. Al Estado total Levinas le opone la apertura al Otro. Ante la tiranía, construye una ética que evita la soledad absoluta de lo político. La figura del tercero no instaura únicamente la cuestión de la justicia (propia del Derecho) sino que apelando a la conciencia llama a la responsabilidad política, definiendo el paso de la responsabilidad ética a la responsabilidad jurídica y política. Si la responsabilidad ética se constituye a partir del desinterés -dejando de lado el privilegio de preservar el propio ser-; la responsabilidad política se instaura porque el sujeto, frente al tercero -siempre presente en el rostro del Otro- no tiene derecho a aislarse de la multiplicidad y de los problemas que esa suscita, revelando la necesidad de instaurar el orden estatal. En suma, la ruptura de la totalidad dio lugar a la alteridad irreductible del Otro; el retorno a la retotalización no deberá implicar una nueva reducción de la alteridad. La política cristalizada en el Estado no deberá anular el desinterés, ni la responsabilidad irreductible.

En Paz y proximidad, analiza la noción de paz en sus dos acepciones. Por una parte, vinculada con la proximidad propia de la ética, donde la proximidad se caracteriza como el vínculo entre el sujeto y el Otro; allí la responsabilidad ilimitada e irrecusable del Yo se cristaliza en términos de una paz para una sensibilidad en la que el escándalo del asesinato no se acalla incluso cuando la violencia es racionalmente necesaria. 
La muerte del Otro y la violencia ejercida no dejan de permanecer en el orden del escándalo inaplazable, injustificable, irreconciliable. La responsabilidad se define aquí en términos de disposición sensible ante el asesinato del Otro. Se caracteriza por no darse en términos armónicos. Esta responsabilidad-ante la muerte del Otro- no deriva de elección propia sino de la disposición sensible del sujeto como pasividad absoluta. Esta proviene de la relación anárquica del cara-a-cara. El sujeto se constituye como único y elegido. En su carácter vulnerable ante el rostro del Otro no puede ser absorbido en totalidad alguna. Paz en relación con una alteridad irreductible que termina siendo relativa. Paz, independiente de cualquier pertenencia a un sistema, independiente a la totalidad, refractaria a la síntesis.

La paz ética no se da en términos de reconciliación con un orden. Sólo es posible a partir de la apertura a la alteridad del Otro. La paz política -reconciliación de lo irreconciliable- será siempre preferible a la guerra. En un mundo de hostilidades ${ }^{12}$,

12 No existe documento alguno en el que se compruebe que Levinas haya leído a Carl Schmidt. Ahora, si hay autor contra el cual se enfrenta y discute es precisamente contra este. Para Schmidt la figura del amigo/enemigo sería la posibilidad conceptual y práctica de fundar lo político o de tener un concepto riguroso de la especificidad política. No sólo entre lo público y lo privado sino entre la existencia pública y la pasión o el efecto comunitario que vincula a cada uno con los otros, como miembros de la misma familia, de la misma comunidad étnica, nacional, lingüística. Para Schmidt el concepto de Estado presupone el concepto de lo político, y no a la inversa, incluso si el Estado -modalidad particular del modo de existencia del pueblo (Volk)- tiene fuerza de ley en los momentos decisivos y en consecuencia constituye el Estatuto mismo. El Estado es el Estatuto, es lo único que puede dar estatuto a lo político. El Estado presupone lo político. El análisis de lo político tiene que privilegiar la forma estatal de esta configuración: el amigo o el enemigo como ciudadano. La despolitización se traduce -según Schmidt- en un movimiento político que tiende a fortalecer la política de partidos y a debilitar el Estado. Cuando la idea de la unidad política -la del Estado- pierde su fuerza, los antagonismos internos superan en intensidad la unidad 0 la comunidad que regula la política exterior. La posibilidad real de lucha refiere a la guerra civil. Esta debilitación del Estado requiere la "pacificación inter-estatal" y hace surgir el concepto de enemigo del interior, público, (polémios u hostis). El enemigo es siempre público. Se interroga Derrida: ¿Cómo puede Schmidt privilegiar el Estado y ver como simétricas la guerra exterior y la guerra civil cómo si el enemigo fuese extranjero o conciudadano? Schmidt describe la guerra civil como una guerra con vista al Estado, una guerra entre un Estado debilitado y un Estado potencial por constituir. Una guerra por la conquista 0 
un mundo sin rostros donde sólo habrá lugar para el Otro en la teoría, la paz política se torna un dilema. Ésta es convocada a partir de la posibilidad del daño entre el Otro y el tercero. Ella castiga pero no repara. La paz lograda políticamente siempre es un proceso abierto a la relación ética de proximidad, a la imposibilidad de reconciliar el dolor del Otro. Entre ética y política siempre hay una tensión que jamás deberá desaparecer para que el orden de lo irreparable no quede absorbido en la reparación. Si el sufrimiento del Otro es lo inasumible, la paz de la totalidad deberá estar atravesada por la paz del desinterés a fin de que el dolor del Otro no permanezca en el orden del sinsentido.

A partir de aquí, ¿cuál es el modelo político levinasiano? La necesidad del orden institucional tiene por finalidad ${ }^{13}$ el límite

reconstitución del poder del Estado. La guerra es una lucha armada entre unidades políticas organizadas; y la guerra civil, es una lucha armada en el seno de una unidad organizada. La lucha siempre es armada. La muerte implicada en el concepto de enemigo no es natural, es violenta puesto que el enemigo tiene que ser matado; ni tampoco, un asesinato, puesto que matar en la guerra no se considera crimen. Schmidt define el antagonismo o la oposición como como teleológicamente política. Define la negación oposicional mediante lo político. Este concepto de la hostilidad -único concepto propiamente político de lo político a los ojos shmidtianos- es también un concepto ético (Hegel). Para Hegel -algo que los pensadores modernos procuran olvidar y ocultar- el enemigo es la diferencia ética. Pensado desde la "vida absoluta" en lo "eterno del pueblo", diferencia que constituye el extraño que ha de ser negado en su totalidad viva. Tal diferencia es el enemigo y la diferencia contemplada como relación es -al mismo tiempo-, oposición del ser a los opuestos, es la nada del enemigo. Para la ética hegeliana este enemigo sólo puede ser enemigo del pueblo y a su vez no puede ser sino un pueblo. Esta guerra - dice Hegel- es de pueblos contra pueblos y con ello, el odio queda indiferenciado. Schmidt pasa del ser-enemigo al reconocimiento del enemigo, a su identificación. Identificación que conduce a identificarme a mí mismo, con el otro, con el enemigo. ¿A quién puedo finalmente reconocer como mi enemigo? Sólo a aquel que puede ponerme en cuestión. Sólo yo mismo, o mi hermano. El otro se revela como mi hermano y el hermano se revela como enemigo. El enemigo habita o alberga en la pregunta. Es nuestra propia pregunta como figura. No puede uno ser puesto en cuestión más que poniéndose a sí mismo en cuestión. Hacer del enemigo aquel que es a la vez el más próximo: yo mismo o mi hermano. El uno no excluye al otro. Gracias a mi hermano soy el otro, y el más próximo es el más lejano, el más propio el más extranjero. El enemigo es el otro.

13 El modelo político de Levinas se define como contra modelo del hobbesiano. Para Hobbes la guerra potencial de todos contra todos - propia del estado de naturaleza- desemboca en el poder otorgado a la espada común. El Estado se constituye con la finalidad suprema de la 
de la relación ética. La necesidad de la institucionalidad política está dada por la virtuosa incapacidad de la ética de no poder dar cuenta de la constatación de la multiplicidad. La figura del tercero reclama un Estado donde la justicia sea posible. Para Levinas, el Estado no se fundamenta en la mera limitación de la guerra. El Estado surge como limitación de la proximidad, relación ética más allá del ser. La instancia a-política es una relación anárquica donde el sujeto -único y elegido- se constituye como responsable ante el rostro del Otro. La responsabilidad significa que el sufrimiento y la muerte del Otro son prioritarios. Ello no implica en modo alguno anular la ética del desinterés. Levinas propone un Estado de la justicia que surgido de la limitación de la ética del cara-a-cara, presente una suerte de totalidad permeable atravesada por la ética, donde no absorba la alteridad del Otro. Levinas muestra que antes incluso de ser una noción política, la justicia es, la responsabilidad ante el rostro del Otro.

La ética resulta una instancia a-política porque el principio de la responsabilidad se sitúa de manera independiente del conocimiento y del ser, independiente de toda tematización. La relación ética anárquica -ahora descripta en términos de

conservación del propio ser, puesta en peligro por el estado de naturaleza como consecuencia de la guerra de todos contra todos. El paso del estado de naturaleza a la constitución del Estado se produce por la renuncia a todos los derechos con excepción del derecho de conservarse en el propio ser. La razón de esa renuncia no es sino salvaguardar la propia vida amenazada en la guerra potencial de todos contra todos. Para Hobbes la conservación -la seguridad de una persona humana, de su vida, de modo no gravoso- es la ley fundamental de la naturaleza. La preservación de la propia existencia es la razón de ser del Estado y por ello, su límite. El Estado no podrá con justicia exceder ese límite en contra del principio por el cual fue creado. En términos levinasianos, el Estado de Hobbes no deja de estar fundado en la ontología 0 en el interés de la esencia; no dejando de ser otra cosa que la garantía de este interés. La ontología -preservación del propio ser- es la razón última de la instancia política; por fuera de ésta, sólo existen individuos egoístas que temen por su propia muerte. El sufrimiento del Otro se justificaría en pos de la conservación del orden. En el Leviatán la idea de justicia sólo tiene sentido en la medida en que se instalan leyes positivas. Fuera de la institucionalidad sólo rigen las leyes de la naturaleza que no proporcionan la medida para el juicio y el castigo. En esa guerra de todos contra todos -señala Hobbes- nada puede ser injusto. Las nociones de derecho e ilegalidad; justicia e injusticia están fuera de lugar. Donde no hay poder común, la ley no existe; donde no hay ley, no hay justicia. La instancia previa a la politicidad es una suerte de anarquía, donde no tiene sentido alguno plantear algún tipo de justicia. 
justicia- será el primer sentido o significación. El Estado justo no puede olvidar el desinterés; así como tampoco de la responsabilidad para con el Otro. La política debe permanecer atravesada por la relación ética, evitando con ello que lo político engendre totalidades cerradas. Si el Estado surge a partir de la limitación de la ética, ésta debe ser su finalidad. La razón del orden estatal es la de brindarle al tercero la posibilidad de justicia. La ética es el exceso de dar al Otro: doy la totalidad del pan de mi boca al Otro; es este dar ilimitado. Siguiendo a Hegel -pero también a Levinas- en el Estado deberá recaer esta obligación. El Estado justo es el que cumple con aquello por lo que fue requerido. Un doble cuestionamiento somete al Estado: su legitimidad depende de que no se anule la relación del cara a cara, que permanezca como totalidad esta vez porosa, permitiendo que la política esté atravesada por la ética; por otra parte, deberá evaluarse si con ella se permite alcanzar la justicia, finalidad por la que el orden estatal ha surgido.

Si el Estado no trasgrede el límite de la ética, si no absorbe la relación ética del "cara-a-cara" y si da un marco de legalidad abierta por el cual se garantice la justicia, estaremos en presencia de una forma estatal deseable. Si el Estado surge demarcando el límite de la ética; la ética, es -a la vez-, el límite del orden estatal. La relación cara-a-cara es la medida para establecer si se está frente a un Estado justo. La política debe poder ser siempre controlada y criticada a partir de la ética. Con ello, la política revela su carácter perfectible. La ética se manifiesta como límite ${ }^{14}$ a la política y es lo que da derecho a la resistencia o rebelión. La justicia como orden que busca reparar lo irreparable. La herida clama justicia. La justicia como escucha del dolor, dando sentido al sufrimiento del Otro pero también, como la posibilidad de evitar la impunidad, como el orden que busca reparar lo irreparable. La relación

14 El límite del Estado no puede trascender la finalidad que le ha dado origen. En J. Locke es fundamentalmente, la protección de la propiedad privada. En T. Hobbes, el Estado no puede atentar sin causa contra la vida de los individuos, pues fue creado con el fin de conservar la vida. En cualquier caso de transgresión de estos límites posibilita el derecho a la resistencia. 
con la alteridad (del Otro y del tercero) convoca a aquello que la ética prohíbe: el sentido del sufrimiento del Otro. La ética -en cuanto imposibilidad de otorgar un sentido al sufrimiento del Otro- se sitúa -respecto de lo político-, en una exterioridad; como si una y otra no debieran rozarse, como si una y otra trazaran caminos diferentes que jamás habrían de encontrarse. El orden estatal -dentro de la perspectiva levinasiana- adviene de la limitación de la relación cara a-cara. Encuentra su fundamento en la posibilidad de justicia para el tercero, incluso para el Otro. El tercero convoca a la justicia -el orden de la igualdad donde se compararan los incomparables-.

La razón de ser del Estado -en tanto limitación de la éticano es otra que la de brindarle justicia al tercero. Lo político no se funda a sí Mismo. La justicia del orden institucional -para Levinas- debe ser considerada a partir de la justicia de la ética de la proximidad, de la apertura a la alteridad del Otro. El orden político no significa trastrocamiento o suspensión de la ética sino una reparación de las heridas del tercero que también es Otro. Ética y política están en continua tensión. Aquello que busca evitarse es que la totalidad política se presente como cerrada sobre sí misma a través de cierta permeabilización de lo ético. Aquello que busca evitarse es reducir la alteridad del Otro a la lógica de la totalidad al absorber la relación ética del cara-a-cara. Ahora bien, el orden estatal atravesado por la ética se establecerá como una suerte de contra modelo. La finalidad del Estado no debe recaer en su propia conservación sino en la garantía de justicia del tercero, de la que la ética no puede dar cuenta y cuya finalidad es la corrección constante de la asimetría y desigualdad. La justicia repara o corrige las heridas del tercero que la ética ha dejado de lado, reparando lo irreparable, remendando el dolor del Otro. Hay en lo político cierto olvido de la alteridad del Otro, aquel exceso que prohíbe el sentido de su sufrimiento, como sí la ética permaneciera por fuera de la política sin poder rozarla.

La filosofía de Emmanuel Levinas busca dar cuenta del "humanismo del otro hombre", del sentido que tiene la vida en 
virtud de la responsabilidad para con el Otro. La desgarradora historia del siglo XX (de la que él y su familia fueran víctimas) le permite intuir que el totalitarismo político es resultado de un totalitarismo ontológico. Subsumir a la humanidad bajo una idea hace que se piense a partir de la ontología y estalle en la política. Su reflexión es el resultado de un apasionante diálogo con la tradición filosófica occidental que siempre ha hecho de la ontología, la filosofía primera. Levinas objetará una ontología que sacrifica a lo Otro en aras de la verdad, del conocimiento, de la objetividad, de la totalización del desentrañamiento del ser.

Frente a una ontología que vuelve inmanente el mundo exterior a la conciencia del sujeto, Levinas reclama por el olvido del otro hombre. ¿Cómo es posible establecer como filosofía primera a la ética? Definiendo a la filosofía bajo la idea del cuidado y responsabilidad por el otro hombre. Una ética que reconoce siempre una exterioridad que se rehúsa a ser integrada. Estamos en presencia de una razón más moderada. No se trata de renunciar al carácter racional de la ética sino hacer ver que la ética deriva de la razón. Levinas impugna la subjetividad trascendental de la talla de la fenomenología; sospecha del egoísmo del Dasein heideggeriano; denuncia el solipsismo del ego cartesiano; desconfía de la filosofía griega en general y de la hegeliana en particular, que siempre han reducido lo Otro a lo Mismo. A partir de aquí, ¿Qué propone nuestro autor? Un sujeto responsable por el otro hombre. Una ética pensada como el resultado de un diálogo con la tradición que la posibilite como alternativa a la ontología. ¿Cuál es su punto de partida? El de la extrema fragilidad, el de la demanda, desde el otro pobre. Es lo superlativo de la debilidad, es tan débil que exige. Son lo apátridas, los oprimidos, los pobres, los sin hogar, las viudas, los huérfanos. Son los vulnerables que siempre son y serán posibilidades que no pueden ser estructuradas de acuerdo a un esquema político. Son aquellos a los que W. Benjamin llamaba "los derrotados y los muertos".

En Totalidad e Infinito Levinas señala a la ética como filosofía primera. No es el yo quien determina lo verdadero sino 
el Otro. La verdad es un encuentro con el Otro (diferente), es una manera de relacionarse con él. Tal relación sólo se puede entender a través de la responsabilidad. El Otro desconcierta a la conciencia que lo mira. Del Otro no hay un contenido que lo llene de significado. El Otro ya no es inmanente, es trascendente y exterior, es inalcanzable, es Infinito. Esta afirmación de la ética como filosofía primera resultará problemática puesto que la filosofía primera debe ser una filosofía de fundamentos -que para Aristóteles estaba más cerca de la ontología que de la ética-, metafísica. La ética no podría ser una filosofía de fundamentos ya que necesitaría dar cuenta de lo evidente, de demostraciones racionales, de lo apodíctico, de un fundamento claro e indubitable a partir del cual, se puedan deducir lo demás argumentos.

La ética -según Levinas- es en encuentro responsable con el Otro y por ello, no es una filosofía de fundamentos. El Otro no se puede encerrar en categorías conceptuales ya que de hacerlo, sería el Mismo y no el Otro. El fundamento es el Otro, ya no más el yo. Si hay Otro exterior al yo, e irreductible a la conciencia, no es el yo el criterio de verdad; tal criterio es el Otro. La verdad es ética. Es un encuentro responsable con el Otro. Levinas no establecerá normas ni criterios de comportamiento; no examinará el contenido de conceptos tales como: Bien, libertad o deber. Nada dice acerca de qué consiste la vida buena. No elabora una teoría de la justicia, ni pautas de evaluación para máximas generales. La reflexión levinasiana se centrará no en contenidos concretos y específicos de lo que hay que hacer, o criterios de validación de lo que se hace. Levinas habla de ahondar en la "naturaleza ética del hombre". Ésta es previa a lo empírico e histórico y a lo ontológico, anterior a las decisiones y a las acciones, incluso a la reflexión sobre ella.

En un texto tardío Levinas marca: "En Europa, pobreza y riqueza miden la nada y el ser" Por eso, el ser es; y la nada, no es, es el no ser. De la nada, nada puedo exigir; el Ser, Europa y Occidente justifican la riqueza. El ser mide la riqueza; la pobreza es medida por la nada. Sólo el ser nos hace ser: occidentales, 
racionales, nos da identidad y nos encadena a ella. Nos vela los ojos para que no podamos ver a los Otros. Desplazar al ser del centro es salirse de Europa para ir a lo otro. Levinas parte de que el pensamiento filosófico es única y exclusivamente ontología, pensamiento del ser, de lo Mismo con la exclusión de la diferencia, de lo otro y más concreta y drásticamente, del Otro. Evadirse es romper el encadenamiento del ser, al propio ser, a la propia identidad, a la brutalidad de la propia existencia. Postula una subjetividad donde el sujeto renuncia a sí para afirmar a los Otros. Levinas propone un ser para los Otros dejando de lado un ser para sí, egoísta. Para nuestro autor, el existir precede al existente. Pero sólo el existente puede dar cuenta del ser. Si el ser es anterior al ente, el existir antecede al existente. En el simple y puro existir no podemos decir que hay algo, pero tampoco podemos decir que haya nada, pues afirmarlo es ya decir algo, afirmar que la nada es de algún modo.

El camino por el que se adentra sugiere que simplemente, Hay, entendido como la ausencia de todo, incluso de la misma nada. El Hay es el ser en general: lo único que hay es el existir. De él no va a nacer el existente, sino que va a tomar conciencia como yo, como identidad, como mónada. El Hay es anónimo, no ha surgido el existente que se afirme con nombre propio. Es la conciencia lo que caracteriza al existente. Antes de tener conciencia, simplemente Hay. Hay el existir pero no el existente. Para que haya algo debe ser nombrado y sólo esto puede ocurrir a través de la conciencia y ella es lo que primero, se diluye en el Hay. Primera noción de tiempo en Levinas: como puro y simple Hay. El existente surge, cobra conciencia de sí y se vuelve un yo. El existir ha sido dominado por el existente que ha adquirido conciencia, la noción de tiempo, de sí Mismo, de libertad y de poder (hipóstasis). Segunda manera de concebir al tiempo, como liberación del existir anónimo. Liberación siempre limitada ya que se trata de un encadenamiento del yo a sí Mismo. Cobrar conciencia de sí es cobrar conciencia del cuerpo y de que la existencia acarrea un peso. Hay en Levinas angustia ante el ser y los Otros. No es miedo a la nada (Sartre). 
El yo es poder que se impuso al Hay y se justifica ante los Otros a través de la responsabilidad. El yo se constituye como un existente que se revela ante el existir anónimo. Al revelarse adquiere conciencia de sí, encadenamiento responsable por sí Mismo, pero en soledad. Hace falta desear lo otro para hacer de la existencia algo soportable.

Levinas plantea -contrariando a la tradición- la posibilidad de erigir una ética sin ontología pero sí, fuertemente vinculada con la metafísica. Una ética que responda antes de conocer el ser, pues se justifica en la responsabilidad por el Otro. Ser es, ser responsable. ¿Cómo entender la metafísica sin ontología? Por ontología se entenderá al intento en el que el yo procura atrapar lo otro a través de las categorías del pensamiento. La ontología es violencia ante lo otro, es la persistente negación de la alteridad. Es convertir en inmanente al yo y todo lo que está fuera de él. La metafísica reconoce que el Otro es trascendente al yo, se le reconoce la diferencia y al mismo tiempo, las limitaciones del yo respecto al Otro al momento de aprehenderlo. Lo Infinito se convierte en un término solicitado a la metafísica. Sólo a partir de que la metafísica renuncia a la pretensión de agotar lo Otro; la ética se entiende -al igual que la ontología- como una relación. Aquí esa relación guarda distancia respecto del Otro. No se trata de violencia alguna sino de responsabilizarme de él. Proximidad es acercarse. Dice Levinas -al hablar de la caricia-: nunca lastimar, aprehender u oprimir la piel del Otro. El Otro es próximo; sin embargo escapa a su total aprehensión. La relación con el otro hombre es metafísica porque el Otro sobrepasa la capacidad que el yo tiene en la conciencia; y es ética, porque a pesar de sobrepasarlo, es responsabilidad por él.

Totalidad e Infinito plantea una distinción entre el yo, que equivale a lo Mismo con respecto a lo otro; o el Otro que es justamente aquel que me mira. El Otro no es meramente, otro yo; es lo que yo no soy. El Otro es el prójimo, el próximo. No exige reciprocidad en su ética. El rostro es siempre desnudez que solicita cobijo. El yo está en la excedencia y por eso la puede derramar hacia el Otro. Jaque a las filosofías dialógicas. 
¿Cómo es posible la reciprocidad cuando del Otro no puedo esperar lo mismo que doy? Levinas afirma una filosofía de la diferencia donde el Otro no es igual al yo de la mano de una ética no dialógica.

Al Otro no lo podemos responsabilizar del yo. El yo va en búsqueda del Otro, no para neutralizarlo sino para pararse responsable y paralelamente ante él. Nuevamente, el cuerpo es sensibilidad, es receptor de la sensibilidad del Otro, es el criterio que distingue al yo del Otro; pero a la vez es el vínculo entre ambos. Permite que el yo sienta al Otro. El cuerpo es la posibilidad del afecto y de la solidaridad, es la posibilidad del encuentro, es la apertura al contacto, al acercamiento, el elemento que permite tocar y ser tocado. El rostro del Otro es un escándalo para el yo toda vez que los Otros fijan la mirada del rostro en el yo demandando responsabilidad infinita. Hace notar Levinas, al yo que está sólo como cuerpo. El rostro irrumpe, es siempre Infinito, no aprehensible, escapa a la conceptualización, no consciente. Es lo exterior en grado extremo. No es fenómeno, es epifenómeno. Es lo trascendente, lo metafísico, lo inmemorial. La ética de la responsabilidad supone: un rostro que demanda; y un yo que salga de sí para ir en busca del Otro. El rostro es la irrupción de lo otro que no se deja reducir a representación, concepto o tema. La conciencia de responsabilidad para con todos es lo único que Levinas intentará elevar al rango de universalidad ${ }^{15}$. Sólo así se admitirá una igualdad entre los hombres. Lo que los haría iguales sería que todos sean declarados responsables por el otro hombre.

¿Cuál es el mecanismo por el cual la ética de la responsabilidad por el Otro resultará posible? El yo no ha elegido su existencia y está amparado en una responsabilidad que nunca

\footnotetext{
15 Levinas rompe con la totalidad precisamente en virtud de que las situaciones concretas son las que impiden la universalidad. Los hombres son iguales en el plano cognitivo, en cuanto tienen las mismas facultades para acceder al conocimiento del mundo. El Otro se constituye en el plano de lo cultural, de lo histórico, de lo económico; de todas las condiciones que nos hacen notar que en esos términos, resultaría absurdo hablar de igualdad.
} 
ha estado en su decisión. Entonces, si el yo no ha elegido su existencia tampoco su responsabilidad. Es la responsabilidad (siempre excedente) la que lo ha elegido. Es una responsabilidad por los Otros y no sólo por mí, incluso por lo que el yo no ha hecho. Es la responsabilidad antes que la libertad. Levinas propone ir más allá con una responsabilidad ética que no sólo responde por lo que el yo ha hecho sino por los actos del Otro. El yo se acusa de ser culpable por los Otros. Responsabilidad indeclinable, sin conocer las causas de aquello a lo que hay que responder. Una responsabilidad desde la ética impone un mandato que viene implícito en el rostro del Otro. Una ética desinteresada -más allá del horizonte del tiempo- que no apele a recompensa mediata o inmediata por aquello que hace por la alteridad.

Vistas las cosas desde esa óptica, se trata de un sujeto que se vuelve rehén del Otro y no meramente responsable. Un sujeto que renuncia a sí Mismo para encargarse del Otro, siempre pendiente del prójimo, próximo a él. Ser rehén del Otro implica quitarse el pan de la propia boca; desvelarse por él, sentir la angustia que el Otro esté en peligro. Implica comprometer la propia existencia. Tiempo diacrónico a partir de la relación con los Otros y donde el yo ya no es más el centro que determina la duración del tiempo. El tiempo se mide por la independencia y dinamismo del Otro respecto al yo. El tiempo es asunto de un sujeto en su relación con los demás. El tiempo es asimétrico. El Otro es para un tiempo al que el yo no alcanzará a vislumbrar en su relación con el Infinito. Si el tiempo es inmemorial, pasado y futuro se miden desde la alteridad, no ya más desde el yo. El pasado no es mío sino del Otro; pero el futuro también. Sólo el presente es presente del yo, pero tal presente solo viene dado del pasado, es decir de lo otro para vincularlo a un futuro, que es también futuro para el Otro. Una subjetividad reducida a la responsabilidad. En De otro modo que ser (...) se explica la figura de un sujeto rehén; ya no más soberano sino a disposición del Otro. Sustitución que rompe con la esencia del ser. Un sujeto rehén es el sujeto ético sometido a la alteridad; un sujeto pasivo que se deja dominar por el orden de la responsabilidad. 
Se trata de dar siempre al Otro sin esperar nada a cambio. El yo es infinitamente responsable del Otro; pero el Otro no tiene responsabilidad para con él. La no reciprocidad salva al Otro de la violencia.

De nuevo, ¿Quién es el Otro sino aquel vulnerable? Si se demanda al yo es, porque sólo él es quién puede aportar la responsabilidad. Ser yo es soberanía pura, poder, fortaleza. Ser yo es siempre exceder los límites del poder. Alguien que se somete -como acto de excedencia- a dar lo que tiene en una ética de la justicia. En la esfera de la responsabilidad ser yo es ser irremplazable por el Otro. La sustitución apela a que el yo ocupe el lugar del Otro; hace del yo un ser para el Otro. La alteridad no es la negación del ser. Para Occidente ser coincide con la esencia asociada a la identidad, idéntico a sí Mismo y al otro hombre. La alteridad viene dada desde un más allá de la esencia, viene de un pasado que el yo no puede recordar. La alteridad invoca a una trascendencia más allá del ser mismo. Por eso, el ser es una limitación de la alteridad.

Más allá del ser está lo Infinito. Recibir (acoger) al Otro, más allá de la capacidad del yo es tener idea de lo Infinito. Una trascendencia dentro de la esfera del ser, resulta una inmanencia. Levinas intuye que ser o no ser quizás no sea una cuestión relevante para la filosofía. A lo mejor lo sea-quizás por primera vez- cómo el ser, se justifica a través de la responsabilidad.

Tal responsabilidad es siempre por el Otro, por Otro que no es idéntico al yo sino diferente, más allá de la esencia, a lo otro que ser. El yo no sería ya una sustancia sino una relación. El hombre es abordado como un ser que padece hambre y frío. En la oscuridad está lo otro, lo que no es luz. Entender al sujeto como ser para Otro donde el sentido de la vida se da en comunidad con la alteridad. Es el Otro el que justifica mi ser. Responsabilidad infinita tendida al Otro donde el yo aprehende del Otro algo que no estaba desde el principio mismo en él (recordemos que para el pensamiento griego aprehender es recordar desde una suerte de hegemonía epistémica) y en tal encuentro desplegar su humanidad. Ahora el Otro ya no es más 
negado sino que enseña su diferencia. La verdad -siendo de corte ético e independientemente de aquello que se entienda por ella- está en el Otro. Edmond Jabés decía que la singularidad es por sí misma subversiva.

II. El diálogo filosófico entre Derrida y Levinas consta de cuatro textos: tres, firmados por Derrida (Violencia y metafísica, 1964; En este momento mismo en esta obra heme aquí, 1980; y Adiós a Emmanuel Levinas, 1997 y; sólo uno por Levinas (Completamente de otro modo, 1973). Entre ambos autores hay una referencia silenciosa, constante, sostenida, empática respecto del discurso de cada cual. Derrida utiliza una metáfora interesante para explicar esta relación cercana: afirma que la herencia nos precede y nos elige, nos invoca antes de que podamos elegirla, y que de alguna manera, estamos obligados a responder a ese legado. Este planteo influye a todo discurso sobre la responsabilidad entendida como algo que procede de lo otro y no de la autonomía del sujeto. Siempre el responder -"de", "a"; "en su nombre"- nos es asignado como herencia. Esa pasividad inherente a la recepción debe ir acompañada de la decisión de decir sí a aquello que se recibe. La decisión de aceptarlo, acogerlo, mantenerlo. Aunque nuestra herencia carece de un sentido unívoco, transparente o, simplemente dado. Ese legado exige tanto como desafía. Levinas nos hablará -en cambio- de filiación. Podríamos decir que Derrida y Levinas se heredan entre sí. Existe en ambos una llamada a reafirmar, atender o mantener el legado que cada uno recibe del otro y que convive con la necesidad de interpretar, escoger y transformar esa herencia. Las tradiciones ${ }^{16}$ griegas y judías confluyen en los dos.

${ }^{16}$ La vinculación entre Occidente y el ser proviene de Grecia. Acontecimiento primero de la pregunta ontológica, el nacimiento mismo de la filosofía. El logos griego se caracteriza por reducir lo Otro a lo Mismo, por suprimir cualquier atisbo de diferencia o por no dejar nada fuera de sí. Tal es así que todo culmina en el absoluto hegeliano; la totalidad es la respuesta filosófica a la pregunta: "qué es el ser?". Existe una estrecha relación entre el totalitarismo ontológico y el político, el cual consiste en fundir las individualidades en una masa indiferenciada. La filosofía levinasiana propone escuchar otra fuente, la judía con el afán de buscar algo que justifique ese ser y que lo encamine más allá del ser. Se trata de 


\section{Ambos ${ }^{17}$ buscan la manera de resistir a la tendencia totaliza- dora de la filosofía occidental para hacer posible una apertura a lo otro y observan que dicha tendencia resulta indisociable del ser entendido como presencia. Los dos están estrechamente vinculados con la fenomenología. Derrida se ocupará en ana- lizar qué es lo que hace posible la comprensión del ser, hasta dónde funciona, y dónde puede verse internamente su fracaso.}

salir del ser corriendo el riesgo de invertir algunas nociones que al sentido y al saber les resultan evidentes. Levinas propone la inversión de la pregunta: ¿por qué hay ser y no más bien nada? (Leibniz, retomada por Heidegger -en una puesta en cuestión entre conciencia, finitud y libertad-) por otra: ¿es justo ser? En ocasiones la alternativa parece otra: ¿Por qué existe el mal y no en cambio el bien? Bien en su significación plenamente ética. El Bien es ese orden ético que interrumpe lo ontológico y que acontece en la epifanía del rostro, recuperando el orden de lo humano. La responsabilidad por el rostro del Otro inaugura el orden ético, el orden de lo humano o también el orden del Bien "más allá del ser". Platón define al Bien de una forma literalmente hiperbólica: como epequeina tes ousias (más allá del ser o del ser del ente). Platón la precisa en el lenguaje de la potencia, de una potencia más poderosa que la potencia, soberana, que corta excepcionalmente con la analogía y la jerarquía que ella impone. Ésta es la esencia sin esencia de la soberanía. Es el origen de una razón que da cuenta de todo, que conoce y da a conocerlo todo, que produce el devenir o la génesis, pero que a su vez no deviene (Derrida).

17 La intención derridiana consiste en mostrar la imposibilidad de un significado que pueda tener lugar en la pura inteligibilidad del logos antes de verse arrojado a la materialidad del significante, de un significado exterior al lenguaje que a la vez ponga en marcha y detenga su juego; la táctica levinasiana consiste en perfilar una relación donde acontezca la significación ética o el sentido de lo humano; significación o sentido que se sitúan más allá de todo juego (más allá del lenguaje, más allá de la historia) y que le sirvan de orientación. El ser como exterioridad que proponía Levinas en Totalidad e Infinito es sustituido en De otro modo que ser (...), por lo otro que el ser. No se trata de buscar otra manera de entender el ser, sino de salirse de él. Para la filosofía, esencia consiste en el acto de ser; el ser diferente del ente. Más allá de la esencia: es más allá del acto de ser, expresión equivalente a "otro modo que ser". Posibilidad de un sentido lejos de la presencia, lejos del ser. El Bien se asocia con el pasado inmemorial -y no con la epifanía del rostro como presencia que vela por su significado- que ningún esfuerzo de la conciencia puede reapropiar; se sitúa siempre más allá del ser. No en el ser como exterioridad, no como trascendencia entendida todavía ontológicamente, sino como de otro modo que ser. El Bien como pasado inmemorial, se sustrae al presente y por ello, a la conciencia. No sólo no puede ser representado sino que tampoco puede estar sujeto a decisión alguna. No se ofrece a los poderes del sujeto. Ajeno a todo ahora, escapa a cualquier intento de apropiación. El sujeto no puede elegir el Bien, sino que es elegido por el Bien. Fracaso de todo poder, pasividad, vocación ética e inasumible. Invitación a pensar al sujeto a partir de su lazo (anárquico) con el Bien. Significación que acontece como proximidad y responsabilidad. 
Levinas, estará empeñado en hallar una salida, que nos lleve más allá del ser. Para ello, propondrá -en Totalidad e infinito-; el ser es exterioridad. Derrida lo criticará en Violencia y metafísica ${ }^{18}$ afirmando que no se puede alterar el logos filosófico inculcándole otro sentido. Insinúa así, la imposibilidad de encaminarse más allá de la tradición -utilizando el lenguaje que esa tradición posee- sin plantearse el problema de las relaciones entre pertenencia y transgresión, el de clausura, el del movimiento del discurso filosófico a cerrarse sobre cualquier pretendido exterior. Sostendrá allí que sólo trabajando sobre sus palabras, sus conceptos, sus sentidos; volviendo contra el discurso filosófico las herramientas que el mismo ha creado resultará posible abrir así las compuertas del logos griego. Enuncia de esta manera, su estrategia: solicitar o reclamar desde dentro, la estructura filosófica. Sin ello, lo exterior corre el riesgo de dejar de serlo, ya que el logos se las ingeniará permanentemente para lograr su permanente reapropiación. Afirma también, que lo exterior está delimitado por el logos y sometido a su ley. La alteridad quedará diluida por ese falso límite; no hay afuera del discurso filosófico. Levinas -en cambio- tendrá otra estrategia, la de abrir el sistema a la fuente hebrea ${ }^{19}$ a la que no renunciará a pesar de las críticas.

La interrogación derridiana se centrará en la finitud de un pensamiento y un lenguaje en que el Infinito no tiene cabida. Quizás sea por esto que Levinas recurra permanentemente a negaciones y metáforas. Encontrar en su lenguaje el elemento de

\footnotetext{
18 Jaques Derrida. La escritura y la diferencia. Traducción de Patricio Peñalver. Primera edición, Editorial Anthropos, Barcelona, España, 1989. Ver Capítulo 4, Violencia y metafísica. Ensayo sobre el pensamiento de Emmanuel Levinas, p. 107 a 210.-

19 En contra de su intención expresa, Levinas permanecerá demasiado fiel al logo-centrismo. Ello le permitirá suturar la apertura a la alteridad, lo cual constituye el gesto logo-céntrico por excelencia. Quizás en Totalidad e infinito este gesto es aún más evidente aunque en De otro modo que ser (...) sigue presente, donde la ruptura anunciada nunca llegará a cumplirse totalmente. Por mantenerse fiel a la tradición judía, Levinas acabaría siendo demasiado fiel a la griega. La filosofía como discurso racional que fundamenta y garantiza a efectos de legitimar la autoridad incuestionable de la maquinaria del saber (sentido-verdad-univocidad) y del poder (autoridad-jerarquía-dominación-legitimación).-
} 
un logos tradicional controlado por la estructura dentro-afuera; interioridad-exterioridad resultará marcadamente dificultoso. Levinas es reticente a la metáfora de la luz por su relación con el poder -una suerte de denuncia contra la "inocencia del discurso filosófico"- que impide pensar la alteridad, sin disolverla. El más allá -hacia el que Levinas quiere guiarnos-, está siempre tomado por todo aquello que pretender exceder: la estructura dentro-afuera; la metáfora del espacio y el espacio de la metáfora; donde el espacio designa -para Derrida-, la finitud misma del lenguaje. El lenguaje se inscribe e escribe en el espacio -señala este último-. Si el pensamiento de Levinas se sostiene sobre la idea de que lo otro sólo es tal, si es infinitamente Otro; y que lo infinitamente otro, es el Infinito ¿Cómo puede un lenguaje esencialmente espacial, esencialmente finito, aspirar a decir que esa alteridad es Infinita? Derrida estaría diciendo que esa alteridad infinita no puede designarse si no es a través de la negación de la exterioridad espacial finita.

El lenguaje sólo puede designar lo infinito recurriendo a la negación. Levinas no puede resignarse a ese fracaso y renunciar a todo lenguaje. En su lenguaje: la metafísica es posibilidad de la palabra. La epifanía del rostro se define como expresión. Sólo el discurso -dice Levinas- puede ser justo y no el contacto intuitivo; y si todo discurso retiene el espacio y lo Mismo en él, eso no significa que el discurso sea esencialmente violento o que la guerra habite el logos filosófico. Hay sí una violencia congénita al discurso filosófico pero si éste es a la vez lo único que instaura y mantiene la separación en la relación yo-Otro, la violencia que comporta no puede ser absoluta. La peor violencia sería la del silencio infinito, señala este autor. El lenguaje sólo puede encaminarse hacia esa paz que lo llama, luchando contra su propia violencia. La experiencia de lo infinitamente otro es el judaísmo. Pero difícilmente se puede pensar la fuente de sentido judía al margen de la conceptualidad griega. Ambos comparten la voluntad de resistir a la tendencia totalizadora de la filosofía occidental para hacer posible una apertura al Otro, sólo Levinas piensa 
esa apertura como sentido ${ }^{20}$ : como el sentido de lo humano, o como significación ética, como búsqueda de una orientación, o justificación para el ser.

El concepto de hospitalidad (no así el de alteridad o el de huella ${ }^{21}$ ) nos permitirá la posibilidad de leer las dos obras en cuestión. En suma, no solamente la preocupación común de apertura a lo Otro sino que sólo ésta se entenderá en términos de hospitalidad. A lo que hasta ahora nos ha parecido como ética -la significación del rostro, la puesta en cuestión de los derechos del yo y la llamada a la responsabilidad- ahora podemos darle el nombre de hospitalidad y hasta sostener que es la esencia del lenguaje. Lo esencial del lenguaje es la relación con el Otro y en la medida en que pone en cuestión mi existencia egoísta y llama a mi responsabilidad, es ética. El sujeto sería entonces, anfitrión y el rostro, su huésped. El término "visitación" adecuado para referirse a la llegada del Otro -en la medida de una llegada impredecible e inesperada- es lo que hace posible que el yo pueda acoger el mandato que cuestiona

20 La apuesta de Levinas es la posibilidad de separar sentido y presencia, única vía para salir del ser y preservar el sentido. Aquello que Levinas discute es la relación entre sentido y verdad, sentido y conocimiento, sentido y contenido-presente y manifiesto de la conciencia-. Discute la preminencia de lo teórico que confirma el parentesco de uno de los pares de esa relación. Invita a romper el privilegio, a plantear la posibilidad de otro régimen de sentido. Se trata del sentido de lo ético, de lo humano, del Bien más allá del ser. Libre de todo intento de reapropiación de la conciencia.

21 La huella cumple en ambos autores una igual función: la de poner en discusión el privilegio que la tradición filosófica ha concedido a la presencia, al presente 0 al ser; ya siempre marcados por algo otro. Esto supone un ataque a la metafísica tradicional así como a la pasión totalizadora de la filosofía. La figura conceptual de la huella impide pensar la presencia, el ser el presente como origen y obliga a concebir algo pre-original, anárquico, no dominado por ella y sin lo cual muy al contrario, ni siquiera sería posible (Levinas). En Derrida la huella aparece vinculada a sus lecturas husserlianas sobre la conciencia interna del tiempo, en particular con el concepto de retención, que señala la iterabilidad constitutiva de todo aquello que se quiere presente. Si esa posibilidad de repetición constituye el presente, sólo llega a ser lo que es remitiendo a una no-presencia, a una alteridad irreductible. La huella implica la imposibilidad de una presencia plena, la imposibilidad del origen, de un punto de partida absoluto que no remita más que a sí mismo en la inmediatez. Ambos coinciden que esa alteridad, en sí misma, no se presenta nunca, no se reduce a un fenómeno. Bien, ocultación, disimulo, enigma son las notas que la describen. 
sus derechos. Si no fuera un ser separado, satisfecho, si no fuera libre, no habría libertad que cuestionar. La orientación del yo hacia el rostro es generosidad. El rostro pone en jaque mi derecho de propiedad y con ese movimiento me desposee del mundo. Reconocer al Otro es instaurar por el don, la comunidad y la universalidad. Ética como hospitalidad, como puesta en evidencia de la injusticia del yo, una llamada a su responsabilidad.

¿Qué es la hospitalidad? Es aquello que se abre hacia el rostro, lo que lo acoge. Pensar la apertura a partir de ella y no a la inversa. Levinas opone hospitalidad a tematización. El rostro no se puede tematizar, es irreductible a él, excede la formalización o a su reducción. ¿Qué es entonces la acogida? Determina la receptividad del recibir como relación ética. Recibir es sinónimo de acoger y sólo se recibe más allá de la capacidad del yo. El yo es vulnerabilidad donde se aloja la obsesión por el otro. En su lectura de Totalidad e infinito, Derrida señalará que la palabra hospitalidad traduce y reproduce dos otras, la de atención y acogida del rostro. Intencionalidad, atención a la palabra, acogida del rostro, hospitalidad son lo mismo. Se trata de una tensión hacia el Otro, intención atenta, atención intencional, un sí dado al Otro. Si bien la hospitalidad se abre como intencionalidad $^{22}$ no podrá convertirse en objeto, cosa o tema. La hospitalidad es la eticidad misma y el principio de la ética. La razón es recibir, sensibilidad, acogida. La hostilidad testimonia asimismo -dice Derrida- la hospitalidad. Para Levinas, la acogida del Otro supone una apertura a lo infinito del Otro y ello, es poner en cuestión mi libertad. Es una respuesta: el sí

\footnotetext{
22 Para Levinas -en su formulación del concepto de intencionalidad- lo pensado -objeto, tema, sentido- remite al pensamiento que lo piensa, pero determina también, la articulación subjetiva del su aparecer: el ser determina sus fenómenos. Levinas endilga a Husserl la herencia del intelectualismo y el privilegio del sentido ontológico del ser. Para el primero la intencionalidad husserliana no es sino justificación de la violencia con la que el yo vulnera al Otro reduciéndolo a lo Mismo. Pese al aparente dominio de la conciencia; Levinas reivindica tres momentos en los que la experiencia de la conciencia intencional fracasa: a.- la intimidad que escapa a la conciencia; b.- la conciencia pre-reflexiva, no intencional, la conciencia desnuda; y c.- la conciencia no intencional como responsabilidad ante el rostro del Otro.
} 
al Otro responderá ya a ello. Se requiere esta respuesta desde el momento mismo en que lo infinito del otro es acogido. Esta respuesta responsable, es ciertamente un sí, precedido por el sí del Otro. No soy yo -sostendrá Levinas-, es el Otro quien puede decir sí. Es el Otro -como afirmación- el que está en el comienzo de la experiencia. Apertura a la trascendencia absoluta del Otro, que está afuera del dominio del sujeto. Derrida cuestionará esa afirmación. Si la decisión y la responsabilidad son siempre del Otro, se preguntará si ellas corresponden siempre al Otro, si vienen del Otro. Iniciativa y responsabilidad son atribuibles al Otro. Para Levinas, que el sí venga del Otro, que la exterioridad radical del Otro sea condición de posibilidad de la afirmación de la subjetividad, no excluye que la responsabilidad sea del yo. Ello no implica inmanencia egológica sino una relación asimétrica, no recíproca, pasiva. Dónde la iniciativa proviene del Otro pero la responsabilidad es siempre del yo. La razón misma es un recibir -acogida de la idea de Infinito- capaz de hacerse cargo de la heterogeneidad que no entiende.

La relación Mismo/ Otro no es una relación cualquiera sino metafísica. Una relación sin relación entre dos términos heterogéneos, absolutos, no totalizables. El yo por una parte; y la alteridad, la exterioridad o el Infinito, por otra. Una relación fundada en la heterogeneidad de sus dos términos; una relación construida sobre una distancia insalvable. La trascendencia designa una relación con una realidad infinitamente distante de la mía, sin que por eso destruya esa relación y sin que esa relación destruya esa distancia. Lo Mismo y lo Otro no tienen nada en común, no se encuentran en ningún punto, no comparten frontera, ni límite, ni pueden servirse de complemento. Entre ellos, no hay reciprocidad, correlación, correspondencia, simetría. En caso contrario, constituirían un sistema cerrado, una totalidad, y ya no cabría hablar de exterioridad, trascendencia o Infinito. La alteridad únicamente puede entrar en relación con algo absolviéndose, separándose; de otra manera perdería su carácter absoluto. Una multiplicidad que no admite la totalidad. La hospitalidad se ofrece o no al 
extranjero, a lo ajeno, a lo otro, al otro. Y lo otro, nos cuestiona, nos interroga en nuestros saberes, certezas y legalidades introduciendo cierta huella, separación e inquietud en nosotros mismos; confrontándonos a nuestro propio desamparo. ¿Cuál es el desafío venido del extranjero? La guerra interna del logos. Es el lugar dónde la hospitalidad se articula con la cuestión del $\operatorname{ser}^{23}$. Espacio de violencia razonada y de amistad ${ }^{24}$. La esencia del lenguaje ${ }^{25}$ es amistad y hospitalidad. A la sacralidad del suelo, fundador de sentido (Arendt) se lo opone la sacralidad de la ley (Rosenzweig y Levinas).

Lo Otro en tanto que Otro no es otro yo. Su alteridad no es reverso de ninguna identidad. No resulta de ella, sino que lo constituye. Nada tienen en común el yo y el Otro. Otro

23 Escribe Levinas: "El asesinato de otro hombre es la imposibilidad para él de decir yo soy"; en tanto ese yo soy es un aquí estoy -señalará Derrida- "del huésped que surge y traumatiza".

24 Aristóteles en la Ética de Eudemo y en el horizonte de la justicia y la política se pregunta ¿qué es justo, que es lo justo en la amistad? Ésta consiste en conducirse en su dignidad -en armonía con el principio de lo justo- como también en su necesidad, cuestión pareja a la de lo bello y lo deseable. La amistad es la igualdad. Un alma en dos cuerpos -decía Aristóteles. Entonces, ¿qué es la amistad?; ¿qué es un amigo? Toda tarea debería consistir en determinar esa justicia. La obra misma de lo político consiste en crear, en producir, en hacer la mayor amistad posible. Amar es lo que hay que entender por amistad. Consecuencia, implicación, es acto antes de ser situación (el acto de amar antes que el estado de ser amado). Hace falta que alguien ame para saber qué quiere decir amar y sólo después ser amado. La amistad es amar antes de ser amado. Amar será siempre preferible a ser amado, como el actuar al padecer, el acto a la potencia, la esencia al accidente, el saber al no-saber. No hay amigo sin el tiempo que pone a prueba la confianza. No hay amistad estable sin confianza pero no hay confianza sin tiempo. Aristóteles habla de los amigos antes que de la amistad. Se trata de singularidades, de ciertos amigos. Se vive con y si hay que escoger; hay que escoger al mejor. Lo que está prohibido es la muchedumbre. La amistad está fundada en la virtud, la igualdad en la virtud. El placer que da la amistad es el placer inmanente a la virtud. La buena amistad exige la desproporción, cuando se estima o respeta más al otro que a sí mismo. Ruptura de la reciprocidad y de la igualdad. Interrupción de toda fusión o confusión entre tú y yo. La buena amistad supone cierto aire de intimidad pero que nos exige cierto abstenernos de toda confusión entre las singularidades del yo y del tú. Comunidad sin comunidad. Amor y respeto. Amor sin Eros, diría Levinas. El cuerpo del amigo, su cuerpo propio podría ser siempre el cuerpo del otro.

25 Dos suspiros, dos nostalgias comparten los exiliados, los deportados, los expulsados, los desarraigados, los nómades: sus muertos y su lengua. Hablar la misma lengua no es sólo una operación lingüística, está en juego el ethos en general. Compartir una cultura, un modo de vida. La invitación, la acogida, el asilo, el albergue pasan por la lengua o por el mensaje a otro. 
es, radicalmente extranjero. Es el rostro quien conservará la heterogeneidad que lo define, la trascendencia inscripta en su alteridad. El rostro se significa, asiste a su propia significación, es expresión. El Otro es caracterizado por la ausencia de cualidades, en su desnudez e indigencia, en su extranjería; cuya sangre -la fuente hebrea- prohíbe derramar. Su absoluta vulnerabilidad se vuelve exigencia, orden, mandato. El rostro impide la negación total, doblega la tentación y el poder de matar al Otro; inaugurando el orden ético. El yo se rinde pero también, cae el discurso por expurgar la alteridad. El rostro significa por sí mismo. Imposibilidad de encerrar su diferencia en una totalidad. Para Levinas lo esencial del discurso no es lo que dice sino que pone en relación con el Otro. El rostro significa por sí, es significante. No anuncia nada, no afirma, ni niega. La imposibilidad ética de $\operatorname{matar}^{26}$ es el sentido. El rostro hace responsable de su mortalidad. La imposibilidad ética de matar unida a la responsabilidad por el Otro es la humanidad misma de lo humano. El yo recibe una significación anterior a su iniciativa. La orden de "No matar" es recibida, acogida. Recibir es siempre, ser enseñado; viene del Otro, heterónomo, sin por ello, perder su libertad.

${ }^{26}$ Lo primero que debe ser pensado desde la perspectiva de Levinas no es la propia muerte (el Dasein heideggeriano) sino la muerte del Otro. A lo largo de la obra levianasiana este pensamiento se articula de distintos modos: a.- como condición de posibilidad de la relación con el Otro. Aquí la angustia ante la propia muerte se vierte en el "temor de poder matar al otro". El yo tiene una responsabilidad infinita en la medida en que descubre que puede matarlo. El rostro del Otro, su alteridad y trascendencia se resiste a esa violencia y es que en esa medida, el yo entabla una relación de responsabilidad. La otredad del Otro, manifiesta la imposibilidad de nuestras propias posibilidades; b.- en un segundo momento, la responsabilidad ante la muerte del Otro se extiende a su condición de mortal: soy responsable en la medida en que se es mortal. Aquí la mirada tiene por foco el hecho de que la estructura del asesinato está implícita en toda muerte. La muerte del Otro me hace sobrevivir como culpable. Un superviviente que siempre será culpable, responsable de lo que ha dejado morir; c.- finalmente, la desmesura del sacrificio, de la capacidad de morir por Otro. En esta suplantación, ve Levinas, lo propiamente humano. El hecho de admitir que la muerte del Otro es más importante que la mía es el milagro de lo humano en el ser, fundamento de todas las obligaciones. No se trata de fundar una ética del sacrificio sino de interrogar el sacrificio como una posibilidad de lo humano. La excesiva gratuidad del sacrificio desborda al hombre como ser razonable. 
Lo esencial del lenguaje no es el qué sino el hecho de que ese mensaje se dirige a un quién. Antes de ser sí mismo, antes de poder ser anfitrión -si por hospitalidad entendemos la acogida que un anfitrión hace en su casa de alguien ajeno a ella- el sujeto ya no habita un lugar propio; es esa apertura, esa acogida. La esencia del lenguaje es ética entendida como una exposición al Otro sin reservas, como el para-el-otro ${ }^{27}$ de la proximidad. Levinas no renunciará al concepto de sujeto. Totalidad e infinito se presenta como defensa de la subjetividad fundada en la idea de infinito. Modo de entender el sujeto desde su recepción o acogida de la alteridad absoluta. Contemplar al sujeto como hospitalidad, donde sólo un ser que tiene cubiertas todas sus necesidades puede llegar a acoger a lo otro. La idea de un yo autosuficiente convive en esa obra con conceptos como creación y revelación, los cuales habilitan a pensar algo anterior a esa existencia. El existente -como aquello que realiza el acto de ser- está dotado de todos los rasgos atribuibles al sujeto: espontaneidad, libertad, capacidad de decisión, posibilidad de ser origen (...). A ello, llama Levinas, soberanía. Esta posición tiene una dura contrapartida, una suerte de encierro del existente en sí mismo. Ambas (soberanía y encierro) van de la mano, implicándose. Ello conlleva a estar clavado en la propia existencia (el Hay). El segundo de los pares sólo se superará en el momento en que se renuncie al primero. Puesta en cuestión de la espontaneidad del yo, ética y que sólo será posible en el momento en que dicha soberanía quede suspendida y que tan sólo ocurre en presencia del rostro. Cuestionar el derecho a poder es cuestionar el derecho a ser. La ética nace del Otro.

El concepto de sujeto que Levinas propone se ve envuelto en su relación con el Infinito. La subjetividad resulta transfigurada en su confrontación con la alteridad absoluta. El yo ya no

\footnotetext{
27 Una de las patrias del judaísmo son las Escrituras y en la medida en que impiden todo reposo en el ser cabe afirmar que esa patria es el no lugar del para-el-otro. Frente al paganismo que es enraizamiento, interés por la propia existencia; el judaísmo es desarraigo, desinterés, responsabilidad por el Otro. El sentido en una exégesis permanente viene a desgarrar el texto, evitando su petrificación.
} 
es origen sino respuesta. El estar-llamado-a-responder le otorga su singularidad, su unicidad. Afirmarse como yo equivale ahora a inclinarse ante la llamada del Otro. Levinas apuesta a que la libertad no tiene por sí derecho alguno y que su justificación sólo resultará posible en relación con el Otro. Para este autor, resulta dable pensar una libertad al margen de la autonomía ya que sólo responderá afirmativamente frente al llamado del Otro. El Otro no coarta mi libertad sino que la inviste, le confiere dignidad, la dota de poderes: de acogida, de don ( $\sin$ intercambio calculable), de manos llenas, de hospitalidad. Sólo aquí podrá hablarse de una libertad responsable. Desde Totalidad e infinito, Levinas subraya la identidad y la soberanía como notas definitorias del yo y a la vez, como aquello que hace posible la hospitalidad. Libertad previa, independiente, y hasta ese momento, autosuficiente. Pero también allí, aparecen los conceptos de revelación y de creación anteriores al yo, que impiden pensarlo en términos absolutos como origen. El yo sólo se confirma como yo a partir del momento en que acoge lo otro; o a partir del momento en que es acusado o conminado a responder. En De otro modo que ser (...) se señala que se pretende poner en cuestión la referencia de la subjetividad a la esencia; donde por esencia habrá que entender: el ser diferente del ente. Poner en cuestión la referencia de la subjetividad a la esencia supone pensar el sujeto como no-lugar, como un perfecto exiliado de sí mismo. La posibilidad de pensar el sujeto sin referencia a la esencia es contemporánea a la propuesta de separar significación y ser. El yo, ya no forma parte -por definición- del orden del ser sino que pertenece al orden de lo ético, al orden de la significación, desde antes de existir como yo y únicamente en virtud de dicha pertenencia. Su apuesta es que la subjetividad se establece exclusivamente como sujeción al Otro. El sujeto no es nada más que ese cuestionamiento. No hay identidad previa a la asignación de responsabilidad. Nada hay anterior a la responsabilidad. Que resuena de un pasado inmemorial, anterior a toda decisión y a todo compromiso, responsabilidad anárquica o pre-originaria. Ante tal asignación 
inapelable sólo cabe responder con el "Heme aquí"28, con el sí incondicionado del más puro ofrecimiento, en una entrega absoluta.

Ello implica disolver la figura de un sujeto soberano y sustituirla por un sujeto hecho de pasividad. La imposibilidad de volver a sí, de reposar en sí, da pie a pensar el sujeto como presa de una inquietud de la que de ningún modo puede liberarse: el yo no es para sí, es para los Otros. El para-el-otro de la responsabilidad convierte al yo en rehén. Aquello que me constituye se revela como un por-el-otro, como movimiento de sustitución o expiación. La responsabilidad implica un vaciamiento del yo, su de-sustanciación, un desgarramiento de la esencia. La subjetividad -en cuanto acontecimiento incesante de sustitución- realiza el más allá de la esencia o el de otro modo que ser. La posición del sujeto se depone. La posibilidad de hablar todavía de un yo se basa en su carácter de elegido. Yo y sólo yo estoy llamado a responder, la asignación de responsabilidad me singulariza, me hace único. La responsabilidad al extremo de la sustitución, configura una suerte de principio de individuación. Este llamado a responder de todos los Otros, sin esperar reciprocidad alguna, involucra una responsabilidad hasta el sin sentido, hasta el absurdo. Responsabilidad, más allá del deber. En relación con el Otro el sujeto está obligado irrevocablemente. Vivimos en una sociedad consagrada a la simple cuantificación de lo útil, del edificio permanente de la eficacia, como si el peligro supremo residiese en lo in-útil, lo carente de objetivos o de metas, en la gratuidad absoluta. Levinas y Derrida parecen desenmascarar la totalización del poder y la fragmentación de la responsabilidad en un gesto político que denuncia precisamente esto.

La dimensión ético-política ocupa en Derrida un protagonismo relevante. El tratamiento explícito de lo ético y lo político se estructura en torno a la falsa lógica de lo imposible. Lo posible,

28 Isaías 6, 8. Aquí estoy o en hebreo: "hineni". Testimonio de un grito con el que se despierta una subjetividad responsable por el Otro. 
nombra el ámbito de lo calculable y previsible, aquello que se puede controlar porque se mueve dentro de un horizonte. Por más que aquel resulte inaccesible funciona teleológicamente, como guía, impidiendo la llegada de lo inesperado. Es a la vez la apertura -pero también su límite-, lo que definirá un progreso infinito o una espera. Derrida establece una estrecha conexión entre lo posible, la soberanía y la presencia. Lo imposible, en cambio, nombra lo que debe seguir siendo ajeno al orden de mis posibles, al orden del "yo puedo". Este imposible no es privativo, no es lo inaccesible, no es lo que yo puedo remitir indefinidamente: se anuncia a mí, cae sobre mí, me precede y no me autoriza nunca a remitir. Es aquello que escapa a mi poder y anula mi soberanía, aquello que nunca llega a presentarse. Verticalidad que dialoga con el concepto de horizonte y que disuelve toda capacidad de previsión. Lo imposible me precede -señala Derrida-. Jamás lo veré llegar, nunca podré actuar a tiempo para resguardarme, ni tampoco le podré poner condiciones. Llama acontecimiento a esta venida incondicionada. El acontecimiento se dibuja entre la espera desesperada y la exigencia inaplazable. Dado su imprevisibilidad e incalculabilidad está asociado a una singularidad excepcional -una relación con lo imposible, diría Blanchot- y por lo que tiene de irruptivo, refiere a ella como la venida del otro o de lo otro. Derrida -frente a la idea levinasiana del infinito que cuestiona la totalidad- va a postular la idea de una finitud constitutiva. El otro es otro finito. Si no se puede designar la alteridad irreductible (infinita) del otro más que a través de la negación de la exterioridad espacial (finita) es que quizás su sentido sea finito. Lo otro no puede ser lo que es -infinitamente otro- más que en la finitud y en la mortalidad. Ello no implicará la reapropiación del círculo de la totalidad, sino la necesidad de que lo otro se dé, en esa misma finitud.

La posibilidad del acontecimiento debe estar amenazada, quizás asediada por la huella de la imposibilidad, imprevisibilidad, incertidumbre. El acontecimiento no debe ser meramente posible, sino imposible, posible sólo como imposible. La lógica de lo imposible debería dar pie a otro pensamiento de lo posible, 
a aquello que Derrida llama el pensamiento del quizás ${ }^{29}$, sólo desde allí se podrá dar cuenta de lo que no se puede anticipar, de lo que nunca es presente. El quizás nombra la amenaza, la incerteza, la indeterminación del arribo del acontecimiento. El acontecimiento estará siempre por venir. La lógica de lo imposible se concreta en una serie de figuras: la hospitalidad incondicional, el don, la decisión, la responsabilidad, la justicia, la exposición sin límite a la venida del otro. Todas ellas refieren a experiencias -que designan la relación con una presencia dislocada, dividida, disyunta, figuras sin límites, sin figuras- que hacen venir o dejan venir el acontecimiento. La hospitalidad ha de ser incondicional e irreductible a la soberanía ${ }^{30}$. Es en Palabras de acogida $^{31}$

29 Derrida retoma la filosofía del "quizás" (vielleicht) nietzscheana que se presenta como un desafío a la certeza del sujeto moderno en sus intentos de reapropiación y auto aseguramiento del conocimiento de lo existente. El "quizás" hace temblar las estructuras del pensar metafísico que se presenta como indubitable, como el fundamento último de lo que es. Nietzsche anuncia en Así habló Zaratústra una nueva forma de pensar la filosofía, una filosofía sin garantías. El "quizás" pertenecería -según Derrida- a un vocabulario exterior a la filosofía entendida como discurso de la certeza, de la verdad, de la veracidad. Posible e imposible aparecen en el escenario estallando la conceptualidad tradicional y exigiendo una articulación inmediata. Para Heidegger el Dasein es posibilidad, es sus posibilidades. En tanto existencia inacabada, es tarea que no remite a una esencia específica, sino que se va realizando en su propio existir. Un existir que no resulta definido de antemano sino abierto al devenir mismo de la existencia para resolverse en él. Derrida afirma que lo posible se presenta de antemano ya asegurado, dado, como posible sin más. Triunfo de lo posible sobre lo imposible, sobre lo impensable, lo que no puede ser planteado, sobre lo que efectivamente da lugar al acontecimiento y lo modaliza desde una posibilidad ya establecida. Pensar lo posible es pensar lo imposible. La filosofía del quizás es una filosofía de lo imposible; que albergue en su seno al azar y que se despliegue en una temporalidad abierta al porvenir que siempre precederá al presente. Una filosofía que aún en su forma oblicua pueda dar cuenta de algo inesperado, incluso inaudible abriendo nuevas formas del pensamiento y de lo político para ayudar a comprender nuestro tiempo. Es allí donde se ubica el acontecimiento, lo imposible, del quizás.

30 Cabe recordar - que en su sentido clásico- no existe hospitalidad sin soberanía del sí mismo sobre el propio hogar. Así como tampoco hay hospitalidad sin finitud. La soberanía sólo puede ejercerse escogiendo, excluyendo y ejerciendo violencia. La injusticia, cierta injusticia o perjuicio comienza inmediatamente desde el umbral del derecho de hospitalidad. Derrida destaca una cierta colusión entre la violencia del poder o fuerza de ley (Gewalt) -por una parte y la hospitalidad -por otra-. J. Derrida, A. Dufournantelle. La hospitalidad -traducción y prólogo Mirta Segoviano- Ediciones de la Flor. Argentina, 2000, (p. 59).-

31 Ésta es el título de una conferencia que Derrida pronunció en la Sorbona en 1996 en homenaje a Emmanuel Levinas Acogida para Derrida es sinónimo -en el pensamiento de 
donde Derrida asocia la hospitalidad incondicional a una lógica de la visitación y la condicionada a una lógica de la invitación. La invitación conserva el control y recibe en los límites de lo posible; la visitación exige una hospitalidad pura e incondicional que acoge lo que acontece como imposible. El invitado es extranjero pero está dotado de nombre y apellido. Su venida responde a un ofrecimiento, a una decisión pensada, es previsible y permite tener todo dispuesto con antelación. Por el contrario, el visitante, es completamente desconocido y anónimo, carece de identidad, no avisa, se presenta siempre por sorpresa, es una suerte de otro absoluto. El anfitrión no tiene control sobre su venida, no le pone condiciones, no pregunta ni siquiera ¿quién es? Lo único que le queda es decir sí. Acoger incondicionalmente al otro implica exponerse, poner el cuerpo, correr riesgos. La hospitalidad incondicional excede el ámbito de lo calculable (excede el cálculo jurídico, político, económico), no espera reciprocidad alguna y es anterior a toda identidad, a toda posesión, a toda soberanía. Ello implica que la ipseidad requiere de la alteridad. El núcleo mismo de la autonomía está atravesado por la heteronomía.

\footnotetext{
Levinas- de Hospitalidad. Levinas busca una instancia pre-originaria dónde anclar una ética a-conceptual, una ética en cuyo seno se instaure lo relacional antes de la tematización, antes de cualquier manipulación donde se acoja al Otro sin entenderlo, antes de haberlo comprendido. Aquí se privilegia la idea levinasiana de apertura al Otro, de atención o tensión hacia el Otro. Derrida rompe con esta primera lectura precisamente aquí, en este texto. El primer Derrida parece ubicar la cuestión política -la economía de la violencia- en un nivel cuasi trascendental, en el discurso mismo y desde allí, la ética es secundaria. En este caso -por el contrario- parece aceptar la posibilidad de materializar una instancia ética en lo político. Derrida piensa la relación de una ética de la hospitalidad como una acogida del otro, una apertura a lo que viene, una política de la hospitalidad, la posibilidad de materializar la ética en un Estado o derecho. Por otro lado, parece también señalar la necesidad de cierta heterogeneidad del orden de la política y de la ética. Derrida se acercará -en sus últimos escritos- a la idea de hospitalidad levinasiana como el lugar para pensar una ética actual. Es indicio de ello la identificación derridiana con la idea de justicia levinasiana como relación con el Otro; ello permitirá la apertura al acontecimiento. Esa hospitalidad ética necesitará de un derecho y una política para realizarse. Jaques Derrida. Adiós a Emmanuel Levinas. Palabra de acogida, traducción de Julián Santos Guerrero, Mínima Trotta, Editorial Trotta, Madrid, 1998, pp., 33-155.-
} 
Esa decisión deberá ser inesperada, irruptiva, incalculable. Sólo en la renuncia de toda soberanía, en la pasividad más absoluta podrá tomarse eso que llamamos decisión. Saber y decisión son órdenes heterogéneos, abismales ya que el primero no es más que una forma de poder, un determinante, previsible, condicionado. Tampoco la decisión puede ser el resultado de la aplicación de una ley, de una norma, de una regla; ello ordena que se actúe simplemente por deber, de manera autónoma. Derrida considera el deber también, como una condición. Todo deber conllevará siempre una deuda que se ha de saldar y toda decisión, la vocación de pagarla. Derrida apuesta a que la decisión ha de tomarse más allá de toda deuda, habla de un sobre-deber, que ordena que se actúe sin deber. La decisión ha de ser, una suerte de invención: única, imprevisible y repentina. Sólo así se podrá atender a la singularidad de cada caso, siempre otro y diferente. Se trata de no saber lo que se tiene que hacer, modo de evitar la buena conciencia ${ }^{32}$ o la tranquilidad del deber cumplido. La decisión ha de rasgar el horizonte del saber y el deber, ha de ser incalculable. Debe decidir y para hacerlo, no puede simplemente quedar al margen de todo deber y de toda regla, aunque sea un deber o una regla que ella invente o reinvente. Nunca hay garantías que una decisión se haya producido, seguimos sin saber si eso que ha tenido lugar, merece el nombre de decisión.

32 Derrida sostendrá -en su lectura de Kierkegaard- una ética absoluta que contra la buena conciencia asuma su culpabilidad ante la muerte del otro y cuyo modelo de actuación sería el que tuvo Abraham con Dios, cualquier radicalmente otro, todo otro es para mí, el otro absoluto. La respuesta a todo otro sería entonces, tal y como quería Levinas, el "Heme aquí", comportarse con todo otro, como lo haría un caballero de la fe, aquí radica lo extraordinario de la acción de Abraham. El otro no es necesariamente, el que está presente, el vivo. Podríamos decir que existe coincidencia con el Levinas de De otro modo que ser (...) donde el otro pierde su fenomenalidad y su presencia. Sin embargo en el silencio y la imposibilidad de hablar, rompe con la estructura levinasiana. Aquello que dice el silencio de Abraham es que la singularidad es inconmensurable con la realidad y el discurso. Quien habla no se dice nunca a sí mismo. La singularidad es la resistencia a toda referencia directa y a todo discurso totalizador. Kierkegaard lo Ilama interioridad o subjetividad y Derrida, lo nombra Dios, una apuesta por repetir la religión sin religión, la posibilidad de guardar un secreto. 
La decisión es siempre entonces de lo otro. Sólo de este modo, puedo decir que la decisión ha sido libre. No hay libertad allí donde se ejerce un poder soberano. Libertad y soberanía son para Derrida, incompatibles. Opone, heteronomía -sin servidumbres- pero responsable; al poder de un sujeto, a la autonomía de la voluntad. Responsabilidad en respuesta a la llamada de lo otro, que no dependerá de ninguna decisión sino que me he comprometido antes de que yo haya podido hacer nada. La llamada de lo otro cobra en el lenguaje derridiano la forma de una mirada: ya sea la de Dios que obliga a Abraham $^{33}$

33 En un texto temprano titulado Existencia y ética 1(963) artículo contenido en Noms propres, Monpellier, Fata Morgana, Paris, 1976, (p. 113) Levinas critica a Kierkegaard la definición del ámbito de lo ético en el clásico Temor y Temblor. Éste último, opondría en su lectura del sacrificio de Abraham la afirmación de la subjetividad frente a lo ético entendido como la esfera de la generalidad y el discurso. En este sentido habría una prioridad de lo religioso, como ámbito del secreto, del silencio, de la verdad indecible que sufre, de la subjetividad atrincherada, sobre lo ético como espacio de la comunidad y por lo tanto, de la intersubjetividad. La fe aísla al creyente del resto de los hombres, hasta el punto de sacrificarlos por obediencia (Abraham con Isaac). Lo religioso requiere de una suspensión del orden ético; Kierkegaard lo llama la "suspensión teológica de la ética" como condición para comprender la acción (de Abraham). Levinas reprocha a Kierkegaard, la violencia que él no se permitiría en su propio discurso. Para Levinas, lo ético no reside en el orden de la generalidad sino en el del encuentro con el Otro, el cual tiene la prioridad sobre el yo. El yo ante el Otro es infinitamente responsable. La subjetividad es en esta responsabilidad. Esto es la ética. Levinas condena el silencio de Abraham. Levinas articula lo ético a partir de la estructura "morir por el otro". La lectura que Kierkegaard realiza del pasaje bíblico -tal como lo demuestra Derrida en Dar la muerte- es la de dar la muerte al otro en virtud de una instancia superior. La estructura que Levinas defiende aparece también en Temor y Temblor, es la acción que realiza el héroe trágico, pero no así el padre de la fe. Si Abraham hubiese dudado, si se hubiera dado en sacrificio, si hubiese muerto en el lugar de (...) se habría comportado como un héroe trágico, pero no como caballero de la fe. La fe consiste en dar la muerte a lo más amado, en responder a la exigencia desmesurada del otro. "Heme aquí" porque se cree (absurdamente) que el objeto del sacrificio no nos será arrebatado. El ámbito de la creencia implica la suspensión de lo ético y la incomunicación. Abraham no puede hablar porque de hacerlo sería perder su responsabilidad, romper el pacto de obediencia, traducirse a lo general. Derrida propone una lectura ética de lo religioso. Para ello, dirá que Kierkegaard repite sin religión la posibilidad de la religión. La suspensión de la ética - llevada a cabo por Abraham- quizás implique -dice Derrida- la aparición de una segunda ética. Derrida opondrá la ética del deber absoluto -una responsabilidad infinita que toma como modelo el sacrificio de Abraham- a la ética universal de los deberes y derechos, a aquellas éticas basadas en la universalidad, la generalidad y el discurso. 
a sacrificar a su hijo; ya del espectro que reclama justicia en la figura del padre de Hamlet. Aquello que me mira me coloca en una posición disimétrica, pues no puede a su vez ser visto. No está en mí responder sí o no. Para ser una llamada de lo otro, ha de permanecer no identificable, no re-apropiable. Ni siquiera hay sujeto que exista previamente a esa interpelación.

Ser responsable es haber respondido con un sencillo -a la vez complejo- sí, a esa llamada que nunca ha llegado a estar presente. Absoluta es aquella responsabilidad ${ }^{34}$ que no se presenta, que permanece secreta, aquella que se asigna singularmente y que de ningún modo se comparte. Absoluta es aquella responsabilidad, que incomunicada hasta el extremo, no responde. Y si efectivamente hay que responder, será sólo comprometiendo esa responsabilidad incondicional. El sí incondicional no constata nada sino que produce un compromiso, me hace responsable, me obliga a responder de aquello a lo que asiento. Derrida lo asemeja a un per-formativo absoluto. El sí incondicional no se da al margen del lenguaje, todo lenguaje lo presupone. Pero aquello que él hace posible arruina su incondicionalidad. Debido a su carácter de promesa, el sí condicional va ligado a su confirmación en otro sí. Éste sólo encontrará su ocasión de acontecer en aquello que, exponiéndolo a la repetición, amenaza su incondicionalidad, ya sea una lengua concreta siempre traducible, su estructura de respuesta, o su propia división interna.

Retomando la relación entre hospitalidad incondicionada y la condicional. Entre ambas hay una relación sin relación de familiar extrañeza, de singular complicidad. Ambas no son exactamente opuestas. A pesar de su heterogeneidad una u otra se exigen mutuamente. En cuanto incondicional, no debe poner

\footnotetext{
34 Ver J. Derrida. Dar la muerte. Editorial Paidós, España, Barcelona, 2000. Allí Derrida de pregunta: ¡En qué condiciones puede haber responsabilidad? Y contesta: siempre y cuando el Bien sea una relación con el otro, una respuesta al otro: experiencia de la bondad personal y movimiento intencional. Una bondad más allá del cálculo, movimiento de don, de amor infinito, más allá de sí misma. (p. 55). (...) Soy responsable ante el otro en cuanto que otro, le respondo y respondo ante él. (...) (p. 70).-
} 
condición alguna, no debe preguntar a aquél o aquello que acoge qué o quién es, de dónde viene o con qué propósito ha llegado, ni tampoco requerir reciprocidad alguna. Por otro lado, no puede hacerse efectiva, más que al precio de comprometerse a una serie de condiciones. En la media en que lo comprima entre límites -legalizando la acogida, que garantice ciertos derechos y deberes, tanto como anfitrión o como huésped- traicionará el imperativo de hospitalidad. La gran denuncia de la deconstrucción derridiana -quizás en su primera fase- es que todo aquello que quiere ser puro, idéntico o cerrado sobre sí mismo, está atravesado o conminado -desde siempre- por una alteridad irreductible.

Ya aquí Derrida involucra una referencia implícita a la hospitalidad para con el otro. Toda relación consigo comporta, de manera irreductible, una relación con lo otro. Esta apertura se corresponde con el momento incondicionado de la hospitalidad. La alteridad no se da nunca al margen de la repetición. Una misma fuerza implica que lo incondicional no se reduce nunca al contexto concreto en el que se ha encarnado, la apertura hace posible la alteridad. Alteridad y repetición se exigen mutuamente. La caída del Uno prohibe fijar un centro, origen y telos. Imposibilidad de un sentido, del significado trascendental, principio y fin del juego del lenguaje. Ello no sólo afecta el terreno de la identidad sino que tiene graves repercusiones con relación con lo otro. Esa alteridad sólo adviene de la mano de un mecanismo de repetición que hace su singularidad, a la vez posible e imposible. Cualquier intento de ignorar o reducir este vínculo equivaldría a privar al acontecimiento de toda oportunidad.

Tanto Levinas -en De otro modo que ser (...)- como Derrida comparten la crítica a la soberanía, característica definitoria de la subjetividad como concepto filosófico. Ambos apuestan a desterrar ese dominio de sí en el que se basa la responsabilidad tradicional. Derrida muestra un sujeto en deconstrucción, cuya vuelta a sí, el retorno a uno mismo que constituye la ipseidad -en la operación de oírse-hablar- no cierra el círculo, implica 
una diferencia. La producción de la identidad incluye una alteridad irreductible. La constitución del sujeto es inseparable de un proceso de destitución del soberano. Ese doble movimiento de institución y destitución en el que el sujeto se produce está presente en la obra levinasiana. La voluntad de poner freno a los poderes del yo, el enfrentamiento a la soberanía absoluta, son ejemplos de ello. Aunque -recordemos- la revelación, la creación, la huella -claramente presentes en los textos- revelan la idea de que algo es anterior a esa soberanía, lo cual invalida su carácter originario.

En Lenguaje y proximidad, de 1967, Levinas deja de insistir en la soberanía del yo, abandonando la red conceptual de la separación. Lo que se plantea -de ahí en más- es un sujeto desvinculado de la esencia, ya no autónomo sino exiliado. Un sujeto que antes de ser, significa (sólo siendo para-el-otro llega a ser para-sí -dice este autor-). El sujeto ya no se definirá por su soberanía sino por su pasividad. Encuentra algo que ni ha elegido, ni se ha dado a sí mismo, ni puede dominar: la responsabilidad infinita por el Otro, hasta la sustitución. Lo que constituye la subjetividad será -de ahora y en adelante- la inspiración por el Otro, exposición al Otro como irreductible a quien no puedo conocer ni nombrar. Una heteronomía que consiste en pensar la subjetividad bajo la sustitución del otro en mí, rompiendo cualquier identidad y presentando una alteridad que se cuela en ese pliegue. Esta exposición al Otro -en tanto que Otro- es lo que funda la relación ética y es lo que hace que adquiera gravitación de filosofía primera, puesto que soy responsable y no libre del Otro. Derrida nos dirá que ya no se trata de pensar al yo cómo término perfectamente constituido que abre las puertas de su morada a la trascendencia de lo otro sino inquietado -desde su interior más profundo- por una alteridad que le impide reposar en sí. Esta idea expresada en una serie de figuras -recurrencia, persecución, obsesión, rehén, inspiración, sensibilidad, vulnerabilidad- conjugan la posición y relevo del sujeto. Hay sin embargo, una diferencia insalvable entre ambos. En Derrida, la división de la identidad, la apertura a lo otro no 
está orientada por ningún sentido; en Completamente de otro modo, Levinas se hace cargo del sentido ${ }^{35}$.

El sujeto levinasiano se define como una pasividad más pasiva que toda pasividad, expuesto desde siempre al Otro y obligado a responder ante él y en su lugar antes de actuar en ningún sentido, antes de proferir un sí o un no. Anterioridad irrecuperable, responsabilidad anárquica, sin origen, sin presente. Una responsabilidad de la que el sujeto no puede adueñarse. La asignación de responsabilidad singulariza al sujeto, funciona como principio de individuación, en la medida en que, como responsable del Otro, resulta insustituible. Subjetividad como hospitalidad, acogiendo al Otro. Derrida ve en la responsabilidad una de las "figuras de lo imposible" y como experiencia precede al sujeto. Los dos encuentran que ser responsable no es responder de uno mismo, de las propias decisiones. Soy responsable del Otro o de lo otro. En ambos se trata de una responsabilidad heterónoma: lo que me hace responsable es lo otro. Respuesta a una llamada que nunca ha llegado a ser presente y puesto que no espera consentimiento, siempre es incondicional. Sólo se hace oír a través de la respuesta, sin que haya mediado mandato. Ese sí incondicional, esa estructura de respuesta -dice Derrida y que no aceptaría Levinas- prohíbe fijar un sí originario. El primer sí, es del Otro. Resultará preciso comenzar a responder.

\footnotetext{
35 Resulta interesante la crítica derridiana para la cual el anhelo de pureza levinasiano sería indisociable de su renuncia a abandonar la noción de sentido y con ella, el intento de pensar la relación con lo otro a partir de "nombres propios" como lo Humano, el Bien o Dios; la insistencia en preservar dicha relación en un fuera de contexto como absoluta, santa 0 separada; cierta insistencia en abrir la relación diádica entre singularidades al terreno de lo universal; la fijación de un origen que se presenta como pre-originario y consiguientemente, el establecimiento simultáneo de su inseparable telos. Derrida denuncia aquí, la presencia de cierta violencia. No es posible pensar la relación con la alteridad a partir de un nombre propio sino sólo a partir de una apertura sin rostro; que dicha relación deberá siempre encarnarse en algún contexto, deberá hacer frente a una multiplicidad de posibles, por los que la negociación será siempre obligada; que no podrá estar anclada en una relación entre singularidades (tout autre est tout autre); que aun siendo siempre anterior a cualquier cosa, no es jamás primera. Para Derrida es condición necesaria para la venida del otro no pensarla como sentido, sino como el tranquilo discurrir entre un origen y un telos.
} 
Cuando se trata de la relación con el otro, Derrida expresa una tensión irreductible entre singularidad y universalidad. Esa tensión también se halla en el pensamiento de Levinas cuándo vincula el rostro y el tercero. Levinas entiende por tercero a aquél que interrumpe la relación entre el yo y el rostro, impidiendo que el cara a cara se mantenga en exclusividad. El tercero inaugura el nosotros, es el Otro del Otro, me fuerza a tomar partido por él, abre el terreno de lo universal. Aún diferente del prójimo, es también mi prójimo y en consecuencia, debo asimismo responderle. Hablar de la apertura al universal es abrir la puerta al lenguaje ${ }^{36}$ y a la objetividad; pero también a las leyes, a las instituciones, a la autoridad política, al Estado. La igualdad de todos se impone en detrimento de la singularidad de los únicos. ¿Qué quiere decir esto? Que la exigencia de justicia ${ }^{37}$ es la que preside la instauración de la sociedad y no al revés. La sociedad justa nace de la

36 Levinas destaca su importancia, es quien señala la necesidad de la palabra para que se dé el vínculo con el Otro, es el autor que cuestiona todo tipo de silencio, silencio que encerraría la peor de las violencias. A pesar de ello, Levinas subordina la escritura al habla y desprecia el lugar del lenguaje como lugar de la totalidad. Derrida señala -una y otra vez- el doble juego levinasiano. Ese reconocimiento del lenguaje y luego su menosprecio. En ese movimiento, Derrida destaca que el lenguaje es violencia Una violencia como espaciamiento y temporalización. El lenguaje es escritura o diferencia (la instancia que da origen a las diferencias). La escritura derridiana se opone a la alteridad absoluta levinasiana, siempre se dice al otro en el lenguaje. Ello implicará reconocer por parte de Derrida cierta fuerza inerradicable y su esencial historicidad. El lenguaje es un movimiento que genera tiempo y espacio, es espaciamiento y temporalización. No hay lenguaje para Derrida sin esa doble posibilidad y por eso es imposible hablar del otro absoluto. Derrida cuestiona la posibilidad de relacionarse con lo absolutamente otro ya que: esa relación con el otro siempre se da en la escritura y no en la plenitud del habla; toda relación de exterioridad se da en el lenguaje; para evitar una violencia hacia el otro sólo se puede apelar a una economía de la violencia.

37 Quisiera hacer mención a la idea cabalística de "tikúm" que generalmente se traduce por "redención" pero en realidad significa "reparación". La Cábala plantea que el mundo contiene astillas del mal, pero también chispas de luz que se desparramaron en el momento de la creación. Violencia en su doble aspecto: creadora y destructora. La luz original estaba contenida en vasijas que se rompieron por no poder contener tanto caudal luminoso. La misión de los hombres sería reconstruir y reparar los recipientes dañados, reunir de nuevo la luz consigo misma. El mundo requiere de la acción humana permanente para mantener su funcionamiento. La manera de reparar es el cumplimiento de las leyes y los preceptos, básicamente velar por la construcción de una sociedad más justa. Conciencia de que el mundo no está terminado, en el que cada día se impone la tarea de corregir los errores, disminuir el monto de maldad y acrecentar la justicia. 
exigencia original del cuidado por el otro, no del imperativo de igualdad formal. Es este principio (el de igualdad formal entre los miembros de la sociedad) el que enmascara la incompatibilidad concreta de demandas -todas ellas subjetivamente legítimas y poseedoras de su propia justificación racional-. Levinas contrapone el origen ético de la política -sin siquiera nombrarlo- con la filosofía de Hobbes, como ya al principio de este texto habíamos señalado, donde la igualdad formal conduce a la lucha de todos contra todos. Qué pretende Levinas? Contraponer la responsabilidad infinita por el rostro del Otro a la guerra de todos contra todos. Para Hobbes -recordemos-, el Estado nace de la necesidad de limitar la violencia, surge del interés; para Levinas, de la necesidad de limitar esa responsabilidad desmesurada ante la presencia del tercero; su origen es -entonces- el des-interés, la no indiferencia por todos los otros. Para Hobbes, el poder del Estado ha de ser absoluto -única manera de hacer efectiva la limitación de la violencia-; para Levinas, el despliegue de lo político encuentra un límite en la relación ética. Único modo de evitar que el Estado sea la continuación de la guerra por otros medios o en términos de una mayor precisión, la instauración de la guerra con buena conciencia.

La idea de que en política se corre el riesgo de ignorar la singularidad del yo es compatible en De otro modo que ser (...) con que el sujeto deja atrás su carácter de rehén, que es aquello que lo singulariza, no poniéndose el énfasis en la pérdida de la independencia. La independencia del ser separado parece ganarse únicamente en el momento en que comienza el reinado de la esencia, la política. Es en esta acogida del rostro dónde se instaura la igualdad. En Totalidad e infinito esa independencia se pierde al acceder al terreno de lo universal. Máxima fidelidad al yo, feliz y despreocupado tal como se lo presenta en la segunda parte de este texto, antes de su encuentro con el rostro, antes de la instauración de la política. En palabras de Levinas: el cara a cara se da "en un entramado de miradas", dónde el tercero me mira en los ojos del Otro. La humanidad nos mira; pero vale una aclaración: no a mí, sino a nosotros. La separación es 
la pre-condición del cara a cara, pero sólo a través del tercero es que estoy unido con el Otro. El rostro es a la vez el prójimo y el rostro de los Otros. La justicia pertenece a la ética-como filosofía primera- y no al imperio de la conciencia.

Se llama justicia -en Totalidad e infinito- a la relación con la trascendencia del Otro. En este libro la justicia estaría en el medio del tercero y el rostro; ya que el tercero o la justicia no se identifican indisociablemente, con el rostro. Hay una resistencia que siempre nos invita a ir más allá. En De otro modo que ser (...) hay una plena asociación de la justicia con el tercero, dentro del ámbito de la universalidad, la objetividad y la política. A pesar de ello, siempre hará referencia a un carácter excesivo, a una permanente inadecuación dentro del propio concepto, como sí nunca llegara a cumplirse plenamente. Si la justicia es la medida aportada al infinito del para-el-otro, entonces nunca podrá darse por satisfecha. Ello significa siempre ir más allá de sí misma. Revisión y esperanza de otra mejor, corrigiéndola incansablemente, haciendo oír la significación ética, la responsabilidad del para-el-otro que el dominio de lo universal tiende a olvidar. Al escuchar el reclamo de justicia -al atender a cada singularidad- se corre el riesgo de ignorar la responsabilidad para con el Otro. Desoír la llamada del tercero, implicará desoír la llamada de la humanidad toda. Para Derrida la ética no sólo corre el riesgo de sufrir la violencia por la entrada del tercero sino que también puede ejercerla si se queda en la pura infinitud del para el otro. El segundo Derrida hablará de la irreductibilidad de la hospitalidad y en cómo construir un orden político en función de ella. Este último va a creer en la necesidad de apertura a la otredad y al acontecimiento.

El tema de la justicia es abordado por Derrida en Fuerza de $1 e y^{38}$ y en Espectros de Marx ${ }^{39}$-obras escritas en los 90'- allí se

38 J. Derrida. Fuerza de ley -El fundamento místico de la autoridad-. Traducción Adolfo Barberá y Patricio Peñalver Gómez. Editorial Tecnos, Madrid, España, 2002.

39 J. Derrida. Espectros de Marx -El Estado de la deuda, el trabajo del duelo y la nueva internacional-. Trotta Editorial, Madrid, España, 2012. Derrida al oponer la ética del deber 
señala que no se puede tematizar u objetivar la justicia, decir: esto es justo y menos aún, yo soy justo sin que se traicione a la justicia y al derecho. Llama a la necesidad de distinguir justicia del derecho ${ }^{40}$, afirmando la imposibilidad de asegurar un criterio que efectivamente los separe. Comienza un análisis fenomenológico del derecho afirmando que no hay derecho sin poder. Una fuerza autorizada, que se justifica o justifque al aplicarse (Kant) incluso cuando esta, puede ser juzgada como injusta o injustificable. En particular a Derrida le interesa remarcar la imposibilidad de distinguir entre la fuerza de ley de un poder legítimo y la violencia pretendidamente originaria que debió instaurar esta autoridad y que no pudo haber sido autorizada por una legitimidad anterior. Apoyado en Husserl y Heidegger, Derrida dará cuenta de una violencia originaria previa a una relación ética: la violencia trascendental y la violencia ontológica. Al principio, la violencia. Para hacer frente a esa violencia

absoluto a la ética universal de los derechos y deberes piensa básicamente en dos argumentos: a.- la ética de los derechos y deberes universales se sustenta en la estructura del sacrificio. En virtud del amor preferencial cuidamos de los nuestros y dejamos morir a los otros. Mi responsabilidad ante el otro implica el sacrificio de todo otro, el otro al que no entiendo, a quien no elijo para amarlo, a quien dejo morir. La buena conciencia quiere ocultar este sacrificio sobre el que se asientan las buenas acciones y razones. El sacrificio de Isaac ilustra la experiencia más cotidiana y común de la responsabilidad. Al preferir al otro, al elegirlo en mi amor y bondad, sacrifico también a mis semejantes, que mueren de hambre 0 de enfermedad. Al preferir la presencia de los vivos, de los que están aquí y me reclaman, traiciono a los ausentes, a los que no están, a los que no han llegado todavía, a los muertos, a los no nacidos; b.- el concepto de responsabilidad que maneja este tipo de ética disuelve la responsabilidad absoluta en el discurso. La generalidad de la ética, lejos de asegurar la responsabilidad nos empuja a la irresponsabilidad. Kierkegaard insiste en que Abraham no puede hablar. Ello sería justificarse ante los otros, hacerse entender, buscar solidaridad y consenso, querer convertirse en héroe trágico y ser admirado por ello.

40 Para Derrida la justicia es una experiencia de lo imposible. Relaciona justicia y aporía: una voluntad, un deseo, una exigencia de justicia cuya estructura no fuese una experiencia de la aporía, no tendría ninguna posibilidad de ser lo que es una justa apelación a la justicia. Cada vez que las cosas suceden o suceden como deben, cada vez que aplicamos una buena regla a un caso particular según un juicio determinando, el derecho obtiene su ganancia, pero podemos estar seguros que la justicia no obtiene la propia. El derecho no es la justicia, es cálculo; la justicia es incalculable. Deberemos asegurar que la decisión entre lo justo y lo injusto jamás esté asegurada por una regla. Derrida es partidario de una justicia infinita, rebelde, extraña a la simetría, heterogénea. 
no es posible apelar a una instancia no violenta por excelencia sino volver una violencia contra otra, realizar una economía de la violencia ${ }^{41}$. Se trata de la relación entre fuerza y forma; entre fuerza y significación. De fuerza performativa, persuasiva y de retórica, de afirmación pero también y sobre todo, el lugar donde la mayor fuerza y la mayor debilidad se intercambian. Señala con acierto Derrida que tanto los discursos sobre la doble afirmación, sobre el don más allá del intercambio y de la distribución, sobre lo indecible, lo inconmensurable, sobre la singularidad, la diferencia y la heterogeneidad son todos ellos, por lo menos, discursos oblicuos a la justicia.

Para Derrida, el discurso es violencia y una instancia que precede y constituye el vínculo con el otro. A pesar de su pretensión de universalidad la justicia siempre se dirige a singularidades, a la singularidad del otro. El lenguaje -como escritura o diferencia- sirve para nombrar un proceso de diferenciación imbricado en una lucha de fuerzas. Si la lucha es una impronta metafísica, la violencia propia del proceso de diferenciación es también una cuestión ético-política. En Derrida existe una tensión entre violencia y hospitalidad; violencia irreductible y hospitalidad irreductible, entre ética y política, entre responsabilidad y procesos de hostilidad-hospitalidad. Siempre una tensión es resuelta a favor de una de las fuerzas enfrentadas. La cuestión es si la tensión misma en su definición no implica una resolución de la tensión entre diversos pares conceptuales. Tensión como diferencia; tensión como movimiento de fuerzas; tensión de indecidibilidad para que sean posibles la decisión y la responsabilidad. Responsabilidad y justicia ejercitadas desde la indecidibilidad.

\footnotetext{
41 Derrida cita a Pascal: Es justo que lo que es justo sea seguido, es necesario que lo que es más fuerte sea seguido. Lo que es justo debe y es justo ser seguido; y luego: lo que es más fuerte, también debe ser seguido. Lo justo y lo más fuerte debe seguirse. Es justo que lo que es justo sea seguido y es justo y necesario que lo que es más fuerte sea seguido. Prosigue Pascal: La justicia sin la fuerza es impotente; una justicia impotente, no es justicia en el sentido del derecho; la fuerza sin la justicia es tiránica. Hay que poner juntas justicia y fuerza para hacer que lo que es justo sea fuerte o lo que es fuerte sea justo. Fuerza de ley, (p. 26 y ss).-
} 
Derrida pone en juicio el carácter fundante de estas representaciones -políticas, culturales, sociales- y del poder que las sostiene, reduciéndolas a meras articulaciones contingentes que operan desde tradiciones o perjuicios teñidos de verdades esenciales. Éstas no son más que parcelaciones o decisiones que operan en un terreno contingente, o dicho de otro modo, indecidibles. No para hacer imposible la decisión o la ley sino para consolidar una nueva forma de estar, relacionarse y producir. Pensar en un mundo deseable a construir, un tipo particular de comprensión vital. Abogará por una nueva apertura ético política, cambio de actitud y de lógica política basada en la fraternidad -como lógica de cohesión e identidad- y en la amistad dejando de lado la pertenencia y la dicotomía amigo-enemigo ${ }^{42}$.

42 Perder al enemigo en el orden de lo político no se traduciría necesariamente en progreso, reconciliación, apertura de una era de paz y de fraternidad humana. Me permito citar a Derrida: (... "sería algo peor: una violencia inaudita, el mal de una maldad sin medida y sin fondo, un desencadenamiento inconmensurable en sus formas inéditas, monstruosas, una violencia en relación con lo cual lo que se llama hostilidad, guerra, conflicto, enemistad crueldad, odio; incluso reencontrarán contornos tranquilizadores y finalmente apaciguadores, puesto que identificables. La figura del enemigo sería salvable en cuanto figura gracias a los rasgos que permiten identificarla como tal: ser identificable, fiable (hasta en su traición) y, familiar. J. Derrida. Políticas de amistad. Seguido del oído de Heidegger. Traducción de Patricio Peñalver y Francisco Vidarte. Editorial Trotta, Madrid, España, 1998, (p. 101 y ss.). Derrida señala también, que no hay amigo sin esta posibilidad del dar muerte "que instaura una comunidad no natural y que sólo podría amar con amistad a un mortal expuesto al menos a la muerte Ilamada violenta, expuesto a ser matado, eventualmente por mí. (...) Amar con amor y con amistad significaría siempre: puedo matarte, puedes matarme, podemos matarnos.". ídem, (p. 143). Pero también señala que "lo que se dice del enemigo no es simétrico y no puede decirse del amigo" La posibilidad o el deber de dar la muerte es lo que suspende, anula, invierte o rechaza, transfigura o sublima la amistad. La amistad consiste en suspender esta estructura de posibilidad. Amar con amor y con amistad sería lo contrario del dar muerte. Finalmente Derrida concluye, lo que liga u opone la pareja amigo-enemigo en la pulsión o decisión de dar muerte sería justamente lo político. La posibilidad real de dar muerte, irreductible condición de lo político e incluso estructura ontológica de la existencia humana significa para Schmidt que procede de una negatividad oposicional que pertenece a la vida, en cuanto que esta se opone a ella misma afirmándose. No a la vida contra la muerte sino a la vida contra la vida, al espíritu contra el espíritu. La guerra procede de la enemistad ya que esta es una negación (óntica) de un ser distinto. La guerra no es sino la realización extrema de la enemistad. No necesita ser nada cotidiano, normal, ideal o deseable sino que tiene que estar presente como posibilidad real. La decisión decide siempre entre el amigo y el enemigo. Discrimina, separa, distingue, diferencia la instancia de la determinación entre los 
Levinas orienta su interpretación hacia la equivalencia de tres conceptos: fraternidad, humanidad y hospitalidad. Acogida del Otro o del rostro como prójimo y como extranjero, como prójimo en tanto extranjero, hombre y hermano. Levinas nos hablará del don del albergue, del asilo y del abrigo. La hospitalidad ofrecida rubricaría por sí una permanencia al orden mesiánico. Se pertenece a ese orden cuando se ha podido admitir a Otro entre los suyos. Ese deber de hospitalidad abre el acceso a la humanidad de lo humano.

La violencia inaugural que instituye el poder de aplicar las leyes, esto es, el poder de ejercer legítimamente la violencia, es pura fuerza performativa ${ }^{43}$, un acto de posición. Dicha violencia fundadora (W. Benjamin) no puede justificarse ante ninguna ley pre-existente: se mantiene suspendida sobre un abismo, su único apoyo es ella misma. Es violencia sin fundamento, tampoco podrá juzgarse legal o ilegal, legítima o ilegítima. Permanece allí, indescifrable. Fundamento místico de la autoridad de las leyes (Montaigne). Derrida relaciona lo místico y el silencio. De la mano de Wittgenstein y de su Tractus lógico-filosófico -séptima proposición- "De lo que no se puede hablar hay que

dos sentidos del término. Matar sin efusión de sangre (donde Derrida convoca a Rosenzweig y Benjamin), con la ayuda de nuevas técnicas es quizás acceder a un mundo sin guerra y sin política, a la inhumanidad de una guerra sin guerra. La matanza de los judíos, gitanos, opositores políticos, homosexuales en la Europa oriental sería un buen ejemplo de ello, la inhumanidad de una guerra sin guerra.

43 Es característico de lo performativo que interviene el cuerpo y se arma una escena: no es puramente verbal. Recordemos que religión y derecho son campos en los que la palabra tiene valor de acto. Pierre Legandre y Enrique Kozicki hablan de la "dimensión estética de la ley" en la medida en que la ley, para regir, necesita de cierta puesta en escena, cierto acto teatral que dé visibilidad y fuerza a la investidura jurídica. En el mismo sentido, tanto el mito como la tragedia y el texto bíblico son performativos: provee a un grupo humano de una escena fundadora -que se reactualiza en el ritual- en la que sus categorías de pensamiento y sus valores se "actúan", se materializan en actos concretos. La aplicación de la categoría de performativo al lenguaje es la inserción de lo físico del acto, lo dramático, en el terreno lingüístico. Poner el cuerpo es siempre involucrarse, arriesgarse, exponerse, actuar. La historia occidental transcurre en el antagonismo, el diálogo, el desencuentro y los conflictos de los cuales la tragedia y el texto bíblico son versiones de lo humano. Porque somos criaturas destinadas a la muerte estamos destinados a la metáfora y a la memoria. 
callar" ${ }^{44}$. Pero mientras que lo místico wittgensteniano es aquello que excede los límites del lenguaje: aquello que se muestra pero no se dice; el silencio del que habla Derrida no es exterior al lenguaje, está encerrado en él. Resulta de lo anterior, la imposibilidad de distinguir entre la fuerza de ley de un poder legítimo y la fuerza performativa que autoriza a ese poder a utilizar la fuerza.

El derecho no está simplemente al servicio del poder, como un instrumento dócil, servil y por tanto exterior; sino que mantiene una relación interna y compleja con él. Si la autoridad de las leyes sólo se obedece por un acto de fe, entonces nada asegura que el derecho sea justo. La justicia es experiencia de lo imposible, de lo que nunca será presente. Un sistema de leyes no es más que un sistema de repetición, de aplicación mecánica, la misma en una multiplicidad de casos. La justicia refiere siempre a una singularidad, a individuos, a grupos, a existencias irremplazables en una situación única. Levinas y Derrida se identifican en un deseo de justicia que se concreta en la negativa de instalarse en el reino de lo universal -del saber, del poder y de las leyes-; en la exigencia irrenunciable de atender a la singularidad sin olvidar que los otros merecen la misma atención. Ambos concentran en el concepto de justicia la necesidad de conciliar la atención a la singularidad con la imposibilidad de detenerse en una singularidad absoluta.

La noción levinasiana de justicia se acerca al equivalente hebreo de la santidad. En Totalidad e infinito, establece Levinas una relación entre política y totalidad -por un lado- y ética e Infinito, -por otro-. Al tiempo en que subraya una clara oposición entre ambos pares, define la política como el arte de prever y de ganar -por todos los medios-, la guerra; cuya posibilidad, permanentemente se manifiesta. Una guerra que suspende la ética y que se produce como la experiencia pura del ser puro, que no manifiesta la exterioridad, ni a lo otro como Otro y que destruye la identidad de lo Mismo pues los absorbe -al uno y al Otro- en la totalidad. Identifica -Levinas- a la guerra con el ejercicio mismo

44 L. Wittgenstein. "Tractus lógico-philosophicus. Madrid, Alianza, 2001, p. 183).- 
de la razón. Ser, totalidad, guerra son sustituidos por el de Bien, el Infinito, la paz. Cuando habla de paz, habla de una trascendencia en la inmanencia, un más allá de la política, dentro de la política. Una paz que excede lo político, un más allá dentro. Una interiorización de la trascendencia ética o mesiánica ${ }^{45}$. Derrida interpreta el más allá dentro de la paz, que a la vez es política y ya no lo es, como un proceso de deconstrucción. Para este último, la oposición guerra y paz no es en sí misma evidente; como tampoco lo es la oposición entre hostilidad y hospitalidad, próximos pero no sinónimos. La promesa de paz mesiánica ${ }^{46} \mathrm{O}$

45 Ernesto Laclau. Emancipation(s) Verso, London, U.K., 2007. Allí Laclau reflexionó sobre el modelo emancipador propuesto por Derrida en Espectros de Marx y su concepto de mesianismo -heredado de la religión pero también de la tradición marxista-. Laclau observará cómo Derrida pasa de un presupuesto ético-político por el cual, esas dimensiones criticadas acabarán convergiendo en el proyecto de democracia por venir, y que a su vez está vinculada a la noción clásica de emancipación, la cual, no es más que otro nombre para el mesianismo escatológico que Derrida pretende sustituir. La noción clásica de emancipación significaba algo más que la mera estructura formal de la promesa; era la concatenación y síntesis de una serie de contenidos y significados que unificaban diversas luchas. Sin embargo, en la sociedad las demandas aisladas, injusticias, opresiones, abusos se identifican no con la tradición sino que se articulan con un nuevo modelo emancipatorio mediante el cual, se formulan nuevas formas de re-agregación política, que en muchos casos se niegan a establecer un modelo determinado y por lo tanto, garantizar una nueva hegemonía. La crítica que Laclau le formula a Derrida -que quizás sea objeto de otra crítica y que excede al presente texto- radica en cómo se produce la transición de esta estructura general de la experiencia (la promesa) a los contenidos del proyecto emancipatorio clásico. En sus escritos tardíos, Derrida trazará un vínculo entre la promesa -entendida como pos-trascendental o post-ontológica- y los contenidos éticos de un proyecto emancipatorio. Laclau llamará a esto "transición ilegítima". Esta consistiría en cómo desde la imposibilidad de una presencia encerrada en sí misma 0 desde una condición ontológica en la que la apertura al acontecimiento, a lo heterogéneo, a lo radicalmente otro se pueda derivar un presupuesto ético que permaneciera siempre abierto a lo heterogéneo y del que se derivaren presupuestos normativos. Para Laclau, -tanto Derrida como Habermas- caerían en la etización de la política. No existiría conexión entre la indecibilidad estructural y una supuesta necesidad ética desde el aspecto ontológico. Si lo social es un campo indecidible, la política es precisamente la operación de sutura que persigue una codificación de la totalidad. Estas codificaciones son el poder, como acto y pretensión de codificar un nuevo sentido, una nueva metáfora desde la que abordar la inconmensurabilidad de la existencia.

46 Isaías 32, 17 “Y el efecto de la justicia será la paz; y la labor de la justicia, reposo y seguridad para siempre"; o el Salmo 85, 11 "justicia y paz se besan". Es en la justicia donde se establecen los mecanismos para mantener y defender el bien-estar y la plenitud del ser 
de hospitalidad infinita que comporta la ética levinasiana debe hacerse efectiva, debe dar lugar a un sistema político concreto. Derrida -que se resiste a ese concepto de justicia cercano a la santidad judía y donde la ética termina siendo "religión" ${ }^{37}$ llama a mediar entre ética y política, para luego señalar que tal mediación es inexistente. Permanece como promesa, promesa que puede no realizarse. Ello no implica la ausencia de relación entre los dos órdenes: es más, debe ésta existir, es preciso que así sea. Apertura a lo otro que sólo es posible como imposible. Sin horizonte de espera, sin anticipación, sin garantía alguna. Una justicia no unida al poder.

Por fuera de programa que me propuse en este texto y al final de su producción filosófica Derrida abordará el tema de la democracia por-venir -como fundamento de la política- e intentará pensarla a partir de la afirmación de que no cabe

humano. La visión judía de la justicia posee las siguientes acepciones: justicia, derecho, solidaridad, liberación, rectitud, generosidad. Es todo aquello que puede llevar a la rehabilitación o restitución del estado ideal del ser humano como imagen de Dios. La justicia tiene como finalidad el bienestar integral del ser humano y de los miembros de la comunidad, en especial de aquellos más vulnerables y en condiciones menos favorecidas. Esta idea se separa de la establecida por el poeta Simónides: "de dar a quien lo que le corresponde" que finalmente, se plasma con Ulpiano en la "firme voluntad de dar a cada uno lo suyo". Toda la legislación política, jurídica, social y económica de Israel estaba diseñada para defender estas condiciones de posibilidad de realización del ser humano, en especial del pobre, de la viuda, del huérfano, del extranjero. Yahveh se manifiesta como padre de huérfanos, abogado y defensor de las viudas, amigo y protector del extranjero y de los desahuciados (D10, 18; Sal 68, 5). La justicia es un instrumento para que el bienestar se realice. Se trata de una justicia restaurativa, no punitiva o correctiva. Restaurar al ser humano, a la creación 0 al Estado a través de la justicia social de la mano de una ética de la responsabilidad, donde el cuidado y el deber es por el Otro, por sus problemas, por su libertad, por su dignidad, por su bienestar. La distinción entre infinitud y eternidad resulta esencial en W. Benjamín donde el progreso -que se despliega en un tiempo infinito- no conlleva responsabilidad, ni acción humana. Redención y rescate de los oprimidos es para Benjamín tiempo mesiánico. Sin el cual el futuro no merece tal nombre.

47 J. Derrida. Políticas de amistad -seguido del oído de Heidegger-.Traducción de Patricio Peñalver y Francisco Vidarte, Editorial Trotta S.A., 1998. Derrida al trabajar el concepto de fraternidad -y a pesar de no ser una obra dedicada a Levinas-, se sirve de la ética levinasiana para criticar el paradigma fraternalista de la tradición, dando a entender que aquel discurso (el levinasiano) contiene al menos un germen de ruptura respecto de ese paradigma. 
democracia sin respeto a la singularidad o a la alteridad irreductible; pero tampoco, sin comunidad de amigos, sin cálculo de las mayorías, sin sujetos identificables. Tensión entre la ley de la igualdad, del número, de las mayorías frente a la ley de la asimetría, de las minorías, de la heterogeneidad. El análisis de esta noción se da básicamente en dos de sus obras: Políticas de la amistad -ya citada- y Canallas ${ }^{48}$. El concepto de democracia es abordado en su conexión con la idea de amistad. Frente a una amistad fraterna -de lo mismo, del reconocimiento de iguales-, habría otra amistad -quizás nietzscheana-, que responde a la ley de la disparidad, una amistad sin medida como resultado del acontecimiento donde entran en juego fuerzas contingentes, no planeadas, azarosas. Nietzsche contrapone: amor al lejano al amor al prójimo. En el primero, apuesta por una radicalidad des-estructurante, por una dimensión del amor como relación liberadora con el otro y lo otro; en el segundo, a una soledad compartida que tan sólo superaría la compasión. En la amistad no hay posesión. Aman su pérdida, su devenir, su soledad y donde lo imprevisible emerge como diferencia y apelación ante la "moral del rebaño", propio del segundo. Aquello que se posee sólo se petrifica. La amistad se afirma en la diferencia y sólo puede existir en la tensión cercanía-resistencia. El azar es el elemento constitutivo de su devenir. ¿Cómo pensar una democracia del venir del otro, donde sólo el otro es portador de la promesa? Habrá que poner en cuestión el intervalo entre lo político y lo común. La pregunta por la comunidad se asienta sobre la problemática de ser-con-otros (ser con el otro o con lo otro) en la acogida de una promesa. Promesa y no pertenencia. Ello nos conduce al desafío de pensar lo heterogéneo, con la consecuente exigencia del respeto de la alteridad. Puesta en duda de la experiencia de la pertenencia -de la clausura de poder subsumirlo todo- y de la propiedad. Puesta en valor de este tiempo de mutación. Sin respeto a la singularidad o a la alteridad irreductible no resultará posible hablar de democracia.

48 J. Derrida. Canallas. Dos ensayos sobre la razón. Editorial Trotta SA, Madrid, España, 2003.- 
Aquél o aquello que viene, aquél o aquello que llega por el otro o lo otro por venir requiere -en cuanto razón democráticala renuncia incondicional de la soberanía -siempre indivisible-. La venida singular del otro -como fuerza vulnerable, débil, sin poder- excede la condición de dominio. Antes de dar, recibe. Antes del don y del ser, es sin ser. Es preciso que dé el tiempo que no hay -dice Derrida-. Es un compromiso con la debilidad de los débiles, de los niños, de los pobres, de todos aquellos/as que reclaman -en medio del sufrimiento- una extensión legítimamente infinita de los derechos del así llamado hombre. Democracia que no es lo que es sino en la diferencia, como experiencia irrefutable de la alteridad de lo otro, heterogéneo, singular, disimétrico, heterónomo. La democracia no se ha presentado todavía, pero ha de venir contra la miseria de millones de mortales abandonados a su suerte: a la malnutrición, a la enfermedad y a la humillación. Pensar la democracia es pensar en el primer llegado -como forma de traducir el primero por venir-, cualquiera fuere este, quienquiera que sea, en el límite. No renunciaremos a utilizar una palabra cuya herencia es significativa $^{49}$-como pensamiento de la libertad (poder, dominio e independencia)- pero cuyo sentido todavía sigue siendo oscuro, obstinado, discreto, opaco, débil, de poca intensidad y valor. Es Levinas quien supedita la libertad a la responsabilidad, responsabilidad antes que la "difícil libertad" y que me convierte en rehén del otro. Experiencia de la heteronomía absoluta pero

49 Es C. Mouffe quien Ilama a potenciar la tradición democrática ya que esto permitirá establecer una conexión con aquellos valores políticos centrales de igualdad, libertad y pluralidad; subrayando el papel que desempeña cada una de estas dimensiones y su significado en el imaginario político para un nuevo sentido común. Mouffe llama a romper con el consenso post-político del interés propio, individualismo competitivo y anti-estatismo reafirmando la naturaleza agonal de la política -una lucha entre adversarios y no entre enemigos (dónde la construcción de un "nosotros" sea la demarcación de un "ellos"). Destaca la tensión entre dos tradiciones: la del liberalismo político y la democrática. La lógica democrática de construir un pueblo y defender prácticas igualitarias resultará necesaria para definir un demos que contribuya a subvertir la tendencia del discurso liberal al universalismo abstracto. Ver para mayor abundamiento Chantal Mouffe. Por un populismo de izquierda -segunda edición-. Traducción de Soledad Laclau, Siglo XXI Editores, Buenos Aires, Argentina, 2018. 
sin servidumbre. La democracia describe los colores vivos y la diversidad, el carácter cambiante, variable, inconstante, a veces complicado, esquivo, equivoco de su andar. Apariencia, creencia, imaginación, representación, suposición y simulacro. Siempre inadecuada e impropia; inacabada e incompleta; siempre insuficiente y futura. A pesar de ello, no se deja idealizar, no es una idea (reguladora) o un ideal (regulador). Lo mismo que el otro, lo mismo que su diferencia irreductible y no re-apropiable es innegablemente real. El por-venir no significa sólo promesas. Es captar lo incalculable en el reino del cálculo. Es comenzar a hacerse cargo de las deudas.

III. Emmanuel Levinas sin duda es uno de los protagonistas del panorama filosófico francés de estos últimos veinte años. Después de la hegemonía del pos-estructuralismo se produce un viraje hacia la ética y la filosofía política y ello conlleva un interés creciente por sus trabajos; pero también lo fue, la vuelta a la fenomenología de los años 80 y 90` y una renovación mundial del interés por los temas religiosos. Es de destacar que el giro ético de la filosofía contemporánea se consolida en la segunda mitad de los años 80'del siglo XX revalorizando la reflexión ético-práctica como solución a la crisis del agotamiento de la racionalidad teórica. La razón científicotécnica ha excluido a la racionalidad práctica del ámbito de la razón. Tanto la hermenéutica, la teoría crítica, la filosofía analítica, los desarrollos posmodernos convergen en su crítica a la racionalidad instrumental alentados por una recuperación de la racionalidad práctica anclados en Aristóteles y Kant. Levinas postulará una racionalidad ética como complemento de la racionalidad teórica. Identifica la racionalidad teórica con la objetivación y con la idea que el conocimiento implica la pérdida de la alteridad de aquello que se conoce. El conocimiento se formaliza y en esta restricción, entiende que la alteridad se pierde, se diluye. La identificación propia de lo conceptual implicará violencia. El conocimiento objetivo sólo alcanza la verdad en su generalidad, en su pacto con lo universal. ¿Qué 
es aquello que Levinas le critica al conocimiento (ya sea idealista o realista)? La incapacidad para alcanzar una auténtica trascendencia; un conocimiento que sólo puede conocer a condición de disolver la alteridad. Denuncia la sinonimia entre conocimiento y ontología ya que la idea de ser es aquella que posibilita la adecuación y por ello, no hay ontología sin objetivación. Propondrá una relación con la alteridad que no anule su trascendencia.

En esta vía se encuentra la ética. Sin embargo, Levinas sabe que no es posible la fundamentación de la ética desde la filosofía de la inmanencia ya que no daría cuenta de una ética que respete la alteridad indiscernible del Otro. Si el Bien no está mediado por nada, Levinas centrará la ética desde una trascendencia que sea irreductible a la inmanencia, de modo que el sujeto no pueda medir la totalidad de lo real. Defensa de la existencia en la sensibilidad de una significación irreductible al conocimiento, que es la proximidad. El sujeto encuentra la alteridad sin absolverla, porque el otro significa a través de un mandato irrecusable y responsable, que me impide ser indiferente y posibilita la apertura del recibir. El mandato es lo que hace insustituible al yo. El movimiento del yo consiste en el Deseo que encierra la idea de infinito descubierta en el rostro del Otro que se aproxima sin adueñarse de su trascendencia. Es en la proximidad del Infinito donde el Bien comienza a tener significado. Es la tendencia hacia el Bien -no hacia la verdad- por el que el Deseo se revela como bondad. El yo por ser finito es diferente, lleva en su seno una huella de la alteridad que le resulta constitutiva. La diferencia lo constituye, lo interpela. Esta racionalidad alternativa debe incluir el encuentro con la alteridad. El Bien no es algo natural o innato; es algo ganado a la realidad. Se accede al Bien desde el contacto con la exterioridad. En la obligación ética del encuentro con el Otro halla Levinas los indicios de una nueva racionalidad: previa a todo conocimiento, inmediata, que no requiere de aclaración posterior, reivindicativa de lo particular y valorativa de la justicia. 
En nombre de la irreductibilidad infinita del otro, Levinas ha tratado de volver a pensar -dice Derrida ${ }^{50}$ - toda la tradición filosófica. Refiriéndose a aquello que en el otro sigue siendo Irreductible, infinitamente otro, desplazando la ontología. Esta última en nombre de lo Mismo y del ser terminaba -desde Platón a Heidegger- reduciendo esa alteridad. Para ello, contrapuso aquello que denominó metafísica o filosofía primera. Levinas parte de una tradición judaica y de una reinterpretación de la fenomenología pero refiriendo a un Platón que hablaba "de lo que está más allá del ser" y conservando cierta fidelidad con Descartes respecto de la idea de Infinito -que "precede en mí a toda finitud"-. Fidelidad infiel con la ontología. No puede haber amistad, hospitalidad o justicia sino ahí donde, aunque sea incalculable, se tenga en cuenta la alteridad del otro como alteridad infinita, absoluta o irreductible. La hospitalidad no se reduce simplemente a la acogida -aunque también lo sea- como actitud primera del yo ante el otro, de rehén; sino a la apertura que es siempre antes. La hospitalidad es siempre primera, antes de ser yo mismo, antes de ser quien soy, es preciso -dice Derrida- que la irrupción del otro haya instaurado esa relación conmigo mismo. Soy el invitado del otro al acoger al otro a mi casa. Ello define mi propia responsabilidad. Soy "presa del otro" cuando digo "Heme aquí". Sin embargo, esa relación está siempre en tensión y la ética ha de fundarse en ella. Desde el momento en que estoy en relación con el rostro del otro, en que hablo al otro, y en que escucho al otro, la dimensión del respeto está abierta. Debemos lograr que la ética esté en consonancia con esta situación y que resista a todas las violencias posibles.

¿Cuál es el papel que juega el tiempo -desde una perspectiva levinasiana- para realizar una apertura de la inmanencia? Si la filosofía de Levinas consiste en una vía para salirse de la inmanencia, la noción de temporalidad se convierte en una clave imprescindible. Levinas propone la noción de diacronía

50 J. Derrida. ¡Palabrasi Instantáneas filosóficas. Traducción de Cristina de Peretti y Paco Vidarte. Editorial Trotta, Madrid, España, 2001, (p. 49).- 
como alternativa a la conciencia, propia de la intencionalidad husserliana. La intencionalidad levinasiana es la temporalidad en contacto con la alteridad no personal. Levinas presenta el tiempo como una relación que preserva la alteridad y por eso, no puede ser intencional. Si la intencionalidad hussreliana -a través de la representación y de la conjunción de tiempo, conciencia y sentir- conduce lo otro hasta la presencia; el tiempo levinasiano (diacrónico) es aquella dimensión de la realidad que escapa a la conciencia, a la presencia, al saber, a la intención, al ser; y dónde se invierte la intencionalidad, el sujeto depone su poder y la racionalidad se amplía. Es en el intento de abrirse a la trascendencia sin reducción alguna a la inmanencia. El tiempo así concebido sólo contiene diferencias cualitativas y espaciales que no son irreductibles a la sincronización que soporta toda definición o determinación de la esencia o sustancia de algo, pura pasividad de la conciencia. Detrás de la presencia se encuentra la diacronía, el devenir de las experiencias, el antes y el después, el pasado y el futuro. Levinas se esfuerza por mostrar el tiempo en tanto que modalidad de acceso a la subjetividad. El referirse al Otro es el tiempo. Tiempo diacrónico, no tematizable, no recuperable por la memoria porque es irrepresentable al no englobar contenido alguno, es la versión del yo hacia el Otro por la que el yo responde del Otro hacia el Infinito. El tiempo es una relación con lo que no está dado, con lo Otro, donde resulta posible descubrir la identidad del sujeto, sin recurrir a sustancia alguna y alcanzar un tiempo no-intencional, irreductible, dando lugar a la novedad de la diferencia. La diacronía consiste en una suerte de realidad de lo imposible: la excedencia de la realidad respecto de la conciencia.

El instante es -subraya Levinas- consumación de la existencia. El instante encierra un acto por medio del cual, la existencia se adquiere. Cada instante es apertura, comienzo, nacimiento, relación, conquista. La diacronía supone que cada instante es otro, es una novedad respecto de otro (instante). Se impone la raíz judía de la noción levinasiana de tiempo. Tiempo como garantía, fecundidad, nacimiento, advenimiento de lo nuevo, 
renovación; en oposición a la concepción griega, de un tiempo ajeno a la noción de creación. Tiempo de degradación, de negatividad, de un proceso de evolución degenerativa, de cambio de más a menos. La materia aportaba la degradación y representaba la caída en lo plural y lo real, tiempo percibido como lo puramente negativo. Por eso, el devenir griego resulta pesimista ya que representa una marcha hacia la muerte. Levinas optará por pensar el instante -no ya en función del tiempo o de la duración- sino en función de la existencia misma, en su acontecer efectivo. Ello implicará pasar a la noción de un sujeto que no se definirá más por el poder, la libertad, el saber, la verdad, ni la disposición sobre los acontecimientos que lo rodean. Temporalizar el tiempo significa para este autor, el encuentro con lo otro concreto que no es conciencia sino heteronomía, que no causa ni fundamenta la conciencia; pero que sin dudarlo, la afecta y determina. Se trata de una nueva modalidad de la conciencia, como pasividad extrema o como de otro-modoque-poder (posición). El ser no agota para Levinas el sentido, no coincide absolutamente con él. Esa no coincidencia resulta ontológicamente irrecuperable, adviene como excedencia, excepción, como humanidad y multiplicidad.

Nietzsche decía que en el origen no está la identidad, sino en la diferencia. Fragmentos, lo diverso y múltiple, lo imposible de reconducir a la unidad, lo que se resiste a entrar a una síntesis totalizadora. Recurriendo a una imagen cabalística se tratará de reunir las chispas dispersas y como en un juego armar con ellas figuras, cuadros móviles, escenas que den nueva condición a la vida. El yo no es el ser que recogiendo los residuos de un instante pasado intenta un instante nuevo, anudando de esta forma -en una sola trama- el hilo entrecortado de la historia. Es exigencia de lo no definitivo, es necesidad de tiempo. Es necesidad de una fecundidad milagrosa en el instante mismo mediante el cual el yo recomienza como Otro. La auténtica obra del tiempo pareciera ser la de liberar al yo de la identidad que lo fija y condena a ser sí Mismo. En armonía con H. Arendt, Levinas considerará al yo como lugar de inicio, en la forma 
de un encuentro liberador con el Otro. El tiempo como inicio evidencia que el ser no se produce de un sólo golpe. Es lo no-definitivo de lo definitivo. Alteridad que siempre vuelve a empezar lo ya cumplido, el siempre de un recomenzar perpetuamente reiterado, en el puro empeño de la existencia. Aquella esperanza del yo que espera en el presente para el presente. El tiempo es discontinuo, no hay continuidad en el ser. Muerte y resurrección constituyen el tiempo. Tal estructura supone la relación del yo con el Otro y en ella, la fecundidad que a través de lo discontinuo, constituye el tiempo. Un tiempo no lineal sino lleno de interferencias, retrocesos, escombros, fantasías incumplidas y gritos no escuchados. La realidad es lo que es, pero será una vez más, otra vez, recobrada y perdonada.

Dos son las maneras principales de entender el tiempo. Una mítica que sostiene y se sostiene en la ilusión de autoengendramiento e inmortalidad, la que diviniza y aspira a la pureza del origen. Otra, la filiatoria, que asume la condición mortal y fallida de lo humano y entiende la eternidad como aquello que se teje en la sucesión de generaciones, la transmisión y la ley. En la primera, el tiempo provoca un incestuoso reflujo sobre sí mismo. En la segunda, el tiempo es apertura e incertidumbre, apuesta y riesgo. Ambas nociones se entrecruzan y solapan tanto en lo individual como en lo epocal y social. Toda tendencia totalitaria regresa al mito, anulando el tiempo y su correlato, la alteridad. Lo hace como origen puro, como sustancia idéntica a sí misma. Toda posición filiatoria -como cifra de finitud y ligadura-, da lugar a lo pasado en tanto pasado y a lo perdido en tanto perdido. Sólo sosteniendo la frágil dinámica entre memoria y olvido, entre continuidad y ruptura, entre conservación y renovación será posible un espacio común, un tiempo abierto, sin negacionismos, ni perdonando lo imperdonable aunque la aporía del perdón ${ }^{51}$ im-posible diga que sólo se pide perdón por lo que es imperdonable. Siempre se deberá

51 Un perdón más allá del cálculo, más allá de la excusa, de la amnesia, de la amnistía, de la absolución o de la prescripción, más allá de la petición de perdón, más allá del 
priorizar dos etapas esenciales: establecer la verdad y hacer justicia. El perdón no hace justicia; así como tampoco no habrá que confundir arrepentimiento con amnistía. Es Jankélevitch el que hablaba del deber de no perdón ya que este puede engendrar el olvido. El perdón -que es siempre un asunto individual- es heterogéneo al derecho. Aunque posible, resultara inauténtico.

\section{Bibliografía}

\section{a. Obras de Emmanuel Levinas}

Levinas, Emmanuel, "La teoría fenomenológica de la intuición". Ediciones Sígueme S.A., Salamanca, España, 2004.

- "Descubriendo la existencia con Husserl y Heidegger". Editorial Síntesis S.A., Madrid, España, 2005.

- "Algunas reflexiones sobre la filosofía del hitlerismo". Colección Popular 626. Fondo de Cultura Económica de Argentina S.A., 2001.

- "De la evasión". Traducción de Isidro Herrera. Introducción y notas de Jaques Rolland. Arena Libros. Madrid, España, 1999.

- "De la existencia al existente". 2 a edición. Arena Libros S.L. Madrid, España, 2006.

- "El tiempo y el otro". Ediciones Paidós Ibérica. Barcelona, España, 1993.

- "Dios, la muerte y el tiempo". Ediciones Cátedra. Segunda Edición. Madrid. España, 1998.

-, "Totalidad e Infinito. Ensayo sobre la exterioridad".. Ediciones Sígueme. Salamanca, España, 1997.

- "De otro modo que ser o más allá de la esencia". Ediciones Sígueme. Salamanca, España, 1995.

- "Entre Nosotros. Ensayo para pensar en otro". Pre-Textos. Valencia, España, 1993.

— "Noms Propres" Fata Morgana. Montpellier. France. 1976.

arrepentimiento transformador. J. Derrida. Canallas -Dos ensayos sobre la razón-, ídem, (p. 178). 
- "Difícil Libertad. Ensayos sobre el judaísmo". Ediciones Lilmod. Colección Estudios y Reflexiones. Fundación David Calles. Buenos Aires, Argentina, 2004.

- "Primera Lección" en "Cuatro lecturas Talmúdicas". Riopiedras Ediciones. Barcelona, España, 1996.

- "De lo sagrado a lo santo. Cinco Lecturas Talmúdicas. Riopiedras Ediciones, Barcelona España, 1998.

- "El Estado del César y el Estado de David" en "Más allá del versículo. Lecturas y Discursos Talmúdicos”. Ediciones Lilmod. Colección Estudios y Proyectos. Fundación David Calles para la Difusión del Humanismo. Buenos Aires, Argentina, 2006.

- "Trascendencia y Altura" en "La realidad y su sombra". Mínima Trotta. Madrid, España, 2001.

- "Trascendencia e inteligibilidad. Seguido de Una Conversación". Ediciones Encuentro S.A. Opúscula Philosophica 26. Madrid, España, 2006.

— "Ética e Infinito". La balsa de la Medusa, 41. A. Machado Libros. S.A., Madrid, España, 2000.

- "Humanismo del otro hombre". Siglo XXI Editores. Distrito Federal, México, 2006.

- "Fuera del Sujeto". Fata Morgana. Cognac, France, 1987.-

- "Los imprevistos de la Historia". Ediciones Sígueme. Salamanca, España, 2006.

\section{b. Obras pertinentes}

"Emmanuel Levinas. Un compromiso con la Otredad. Pensamiento ético de la intersubjetividad". Revista Anthropos. Huellas del Conocimiento $\mathrm{N}^{a}$ 176, Barcelona, España, enero-febrero de 1998.

Abensour, Miguel, "El mal elemental" en Levinas, Emmanuel Algunas reflexiones sobre la filosofía del hitlerismo Fondo de Cultura Económica, Buenos Aires, Argentina, 2001.

Benso, Silvia "The face of things. A different side of ethics" Albany State, University of New York, USA, 2000.

Bensussan. Gérard en "Levinas y lo político. Pablo Dreizick (compilador), Prometeo libros, Buenos Aires, Argentina, 2014.-

Blanchot, Maurice. "Nouvelle Revue Francaise, No 179”, 1967.- 
— "La escritura del desastre", Gallimard, París, 1980

Bloom, Allan. "Gigantes y enanos. Interpretación sobre la historia socio-política de Occidente" GEDISA 1999.

Butler, Judith. "Cuerpos aliados y lucha política. Hacia una teoría preformativa de la asamblea". Traducción María José Viejo, Editorial Paidós SAICF, 2017.

Catherine Chalier. "Levinas. La utopía de lo humano". Traducción Miguel García - Baró, Riopiedras Ediciones, Barcelona, España, 1995.

- "La huella del infinito. Emmanuel Levinas y la fuente hebrea." Traducción de María Pons Irazazábal Herder Editorial, Barcelona, España, 2004.-

Derrida, Jaques. "Adiós a Emmanuel Levinas. Palabra de Acogida." Mínima Trotta. Editorial Trotta S.A., 1998.

- "Violencia y metafísica (ensayo sobre el pensamiento de Emmanuel Levinas)" en "La escritura y la diferencia", traducción de Patricio Peñalver, Siglo XXI Siglo Clave 3 Anthopos, Barcelona 2012.-

— "Dar la muerte". Editorial Paidós, España, Barcelona, 2000

- "Políticas de amistad. Seguido del oído de Heidegger". Traducción de Patricio Peñalver y Francisco Vidarte. Editorial Trotta, Madrid, España, 1998.-

- "Fuerza de ley" -El fundamento místico de la autoridad-. Traducción Adolfo Barberá y Patricio Peñalver Gómez. Editorial Tecnos, Madrid, España, 2002.

- "Espectros de Marx -El Estado de la deuda, el trabajo del duelo y la nueva internacional-.". Trotta Editorial, Madrid, España, 2012.

- "Canallas". Dos ensayos sobre la razón. Editorial Trotta S.A., Madrid, España, 2003.-

- ¡Palabrasi Instantáneas filosóficas. Traducción de Cristina de Peretti y Pacvo Vidarte. Editorial Trotta, Madrid, España, 2001.

- y A. Dufournantelle. "La hospitalidad" -traducción y prólogo Mirta Segoviano- Ediciones de la Flor. Argentina, 2000.

Descartes, René. "Meditaciones metafísicas". Novena edición Traducción del latín por Juan Gil Fernández, Aguilar Argentina S.A. ediciones, Buenos Aires, Argentina, 1980. 
Kronzonas, David. "Emmanuel Levinas: entre la filosofía y el judaísmo". Editorial Biblos, Buenos Aires, Argentina, (2015).

Laclau, Laclau. Emancipation(s) Verso, London, U.K., 2007

Leconte, Mariana. "Racionalidad y Próximidad. La significancia ética como origen de la significación en Emmanuel Levinas" Corrientes, Argentina, 2009.

López Gil, Marta. Liliana Bonvechi. "La imposible amistad. M. Blanchot y E. Levinas". Adriana Hidalgo Editora. Buenos Aires, Argentina. 2004.

Lipsitz, Mario. "Eros y nacimiento fuera de la ontología griega: Emmanuel Levinas y Michel Henry”. Prometeo libros. Universidad Nacional de General Sarmiento. Buenos Aires, Argentina. 2004.

Llewelyn, John. "Emmanuel Levinas. La genealogía de la ética". Ensayos 138. Ediciones Encuentro. Madrid, España. 1999.

G. D. Mole en "Levinas, Blanchot, Jabès. Figures of Estrangement". Gainesville, Univesity Press of Florida, USA, 1997.

Mouffe, Chantal. Por un populismo de izquierda -segunda edición-. Traducción de Soledad Laclau, Siglo XXI Editores, Buenos Aires, Argentina, 2018.-

Stephen, Moses."Systéme et Révelation. La Philosophie de Franz Rosezweig", éds du Seuil, París, 1982

Poirié, Francois. "Ensayo y Conversaciones." Traducción de Miguel Lancho. Arena Libros S.R.L., Madrid, España, 2006.

Salvatore Schiffer, Daniel. "La filosofía de Emmanuel Levinas. Metafísica, Estética y Ética." Traducción de Heber Cardoso. Ediciones Nueva Visión, Buenos Aires, Argentina, 2008.

Sucasas, Alberto. "Emmanuel Levinas: judaísmo y filosofía." (Tesis doctoral).

- "Levinas: lectura de un palimpsesto". Ediciones Lilmod. Colección Estudios y reflexiones. Buenos Aires, Argentina, 2006.

- "El rostro y el texto. La unidad de ética y hermenéutica". Anthropos Editorial. Barcelona, España. 2001.

- "Memoria de la Ley." Editorial Altamira. Buenos Aires, Argentina, 2004. 